Article

\title{
Agroforestry as Policy Option for Forest-Zone Oil Palm Production in Indonesia
}

\author{
Edi Purwanto ${ }^{1, *}$, Hery Santoso ${ }^{2}$, Idsert Jelsma ${ }^{1}$, Atiek Widayati ${ }^{1}$, Hunggul Y. S. H. Nugroho ${ }^{3}$ \\ and Meine van Noordwijk 4,5 (D) \\ 1 Tropenbos Indonesia, Bogor 16163, Indonesia; ijelsma@gmail.com (I.J.); \\ atiekwidayati@tropenbos-indonesia.org (A.W.) \\ 2 Java Learning Centre (JAVLEC), Klidon, Yogyakarta 55581, Indonesia; herys@javlec.org \\ 3 Ministry of Environment and Forestry, Makassar 90243, Indonesia; hunggul@balithutmakassar.org \\ World Agroforestry (ICRAF), Bogor 16155, Indonesia; m.vannoordwijk@cgiar.org \\ Plant Production Systems, Wageningen University and Research, 6708 PB Wageningen, The Netherlands \\ * Correspondence: edipurwanto@tropenbos-indonesia.org
}

Received: 31 October 2020; Accepted: 16 December 2020; Published: 18 December 2020

\begin{abstract}
With 15-20\% of Indonesian oil palms located, without a legal basis and permits, within the forest zone ('Kawasan hutan'), international concerns regarding deforestation affect the totality of Indonesian palm oil export. 'Forest zone oil palm' (FZ-OP) is a substantive issue that requires analysis and policy change. While spatial details of FZ-OP remain contested, we review literature on (1) the legal basis of the forest zone and its conversion, (2) social stratification in oil palm production (large-scale, plasma and independent growers), and (3) environmental consequences of forest conversion to FZ-OP, before discussing policy options in a range of social and ecological contexts. Policy options range from full regularization (as FZ-OP stands could meet international forest definitions), to conditional acceptance of diversified smallholder plantings in 'agroforestry concessions', to gradually phasing out FZ-OP and eviction/destruction. A nuanced and differentiated approach to FZ-OP is needed, as certification of legality along supply chains is vulnerable to illegal levies and corruption. Corporate actors trading internationally can avoid use of uncertified raw materials, effectively shifting blame and depressing farmgate prices for domestic-market palm oil, but this will not return forest conditions or stop further forest conversion. We discuss an agenda for follow-up policy research.
\end{abstract}

Keywords: certification; deforestation; palm oil; forest classification; Jambi; legality; independent smallholders; agroforestry concessions; Sumatra; West Kalimantan

\section{Introduction}

A reader cannot safely assume to understand what the word 'forest' means in any new context, as the ecological (vegetation-based) and social (institutional, rule-based) meanings of the word 'forest' only partially overlap [1,2]. There can be 'trees outside a forest' [3] and 'forests without trees' [4]. Conversion of natural forest to plantation forestry is not considered to be deforestation, an issue that sparked debate when the UNFCCC climate change convention considered forest-specific policies [5]. What is excluded from the 'tree' concept, at the heart of common forest definitions, also matters: rubber (Hevea brasiliensis) can be considered to be a forest tree when grown for timber, or an agricultural commodity when tapped for its latex [6]. A number of global studies, however, have included the conversion of rubber monoculture (regardless of its primary purpose) to an oil palm monoculture under global 'deforestation' statistics [7]. The debate whether or not palms are included under the 'tree' concept has direct implications for whether or not the conversion of natural forest to an oil palm 
monoculture can be called 'deforestation' [8] and for how much a 'deforestation-free' commitment of the palm oil industry means [9]. National definitions of the tree and forest concepts can differ from the global ones $[10,11]$. At the social-ecological system scale of a landscape, the concept of 'agroforest' describes tree-based vegetation managed by farmers, who often see labeling this as a forest as a threat [12,13]. Institutionally such land use may be legalized under 'community-based forest management' rules [14], but these arrangements may maintain forest authorities in the 'landlord' role, expecting a share in any harvestable goods or sellable services that the land may generate [15]. The absence, at least until recently, of formal recognition for agroforestry as a valid form of land use intermediate to 'forest' and 'agriculture' has not prevented the existence and spread of such land uses that defy the rules [16] (Figure 1).

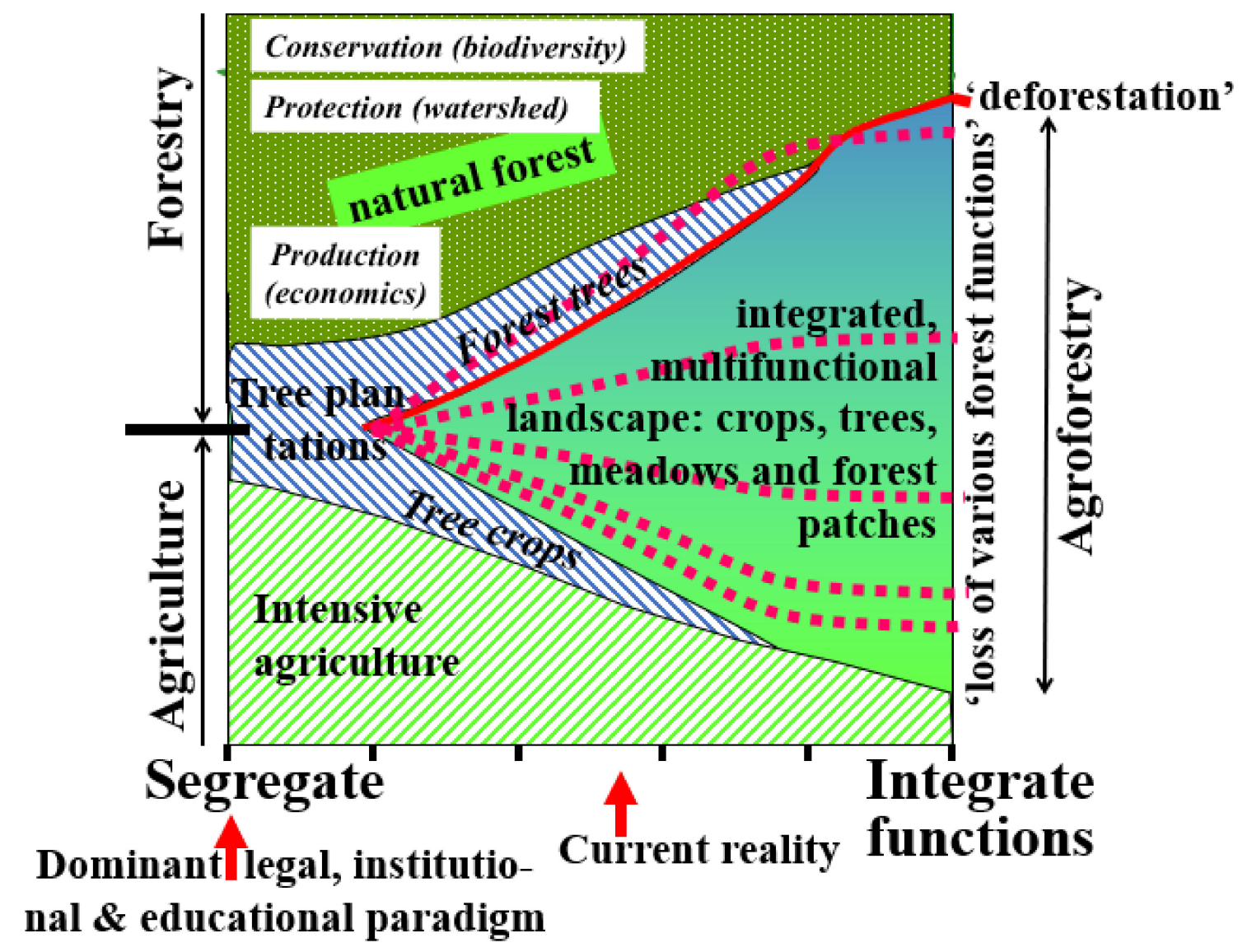

Figure 1. Forest-Agriculture interface with the current segregated policy interpretation distinct from the more fluid 'integrated' reality in the landscape, with consequences for the meaning of 'deforestation' and 'loss of forest functions' [17].

In the international debate over consequences of tropical commodity production, 'forest' is primarily seen as a vegetation type or ecosystem, observable through remote sensing [18], with a rather arbitrary tree cover threshold used in a dichotomous classification. Global data sets based on a continuum interpretation with tree cover as metric are available and have been used to monitor changes in tree cover in agricultural lands [19]. Concerns about deforestation, and the concomitant loss of biodiversity and net $\mathrm{C}$ emissions, have led to institutional support in the climate change convention for government action to support 'reforestation' [20] and 'reducing emission from deforestation and forest degradation' [21,22]. In parallel, citizens in importing countries expressing concern about the footprint of their consumption have induced corporate actors to dissociate themselves from deforestation-linked supply chains [23]. Palm oil has been a primary target for the emergence of voluntary private standards [24,25]. The Roundtable on Sustainable Palm Oil (RSPO) and related 
institutions have triggered responses in Malaysia and Indonesia (jointly around $85 \%$ of global palm oil production) that saw their national sovereignty at risk in international markets [26]. A study of RSPO impacts in Kalimantan suggested that it increased forest conversion in agricultural lands but decreased such within the forest estate [27].

Recent estimates, discussed below, show that, based on remote sensing, 15-20\% of Indonesian oil palms are located within the 'forest zone' (Kawasan hutan), a primarily institutional indication of land status. We indicate these as Forest Zone Oil Palm (FZ-OP). The FZ-OP percentage can be interpreted in multiple ways. To an international audience that has come to believe that most, if not all, of Indonesian palm oil is linked to deforestation, the number may seem to be small. To the Indonesian palm oil sector, it may give the impression of some bad apples that need to be dealt with, as they spoil the good name of the vast majority of those falsely accused of deforestation. To the forest authorities, the numbers are a clear sign of illegality, as current rules do not allow oil palm to be planted within the forest zone as FZ-OP. Actually, oil palms are the most readily recognizable of the four major tree crops (coffee, cocoa, rubber and oil palm) that occur both outside and inside the forest zone [28], but part of the smallholder oil palm may be part of a finer-grained mosaic and not as easily noticeable. Key questions regarding FZ-OP are: (1) What came first: local land use or designation of the land as part of the forest zone?, (2) How does the land use with tree crops relate to the primary designated forest function in (A) production forest (income generation), (B) protection forest (watershed protection) and (C) Conservation areas (Biodiversity), with recent additional interests in restricting drainage of peat soils in the production forest zone, (3) How do the various stakeholders along the palm-oil value chain respond to the lack of legality of forest-based oil palm production?

Issues related to oil palm (and its product palm oil) require an understanding of the whole value chain, as concerns of end-users, often based on limited or biased information they have access to, inform the product manufacturers, who want to be able to claim a 'clean' product, and their suppliers, the partly refined products derived from Crude Palm Oil (CPO), processed from Fresh Fruit Bunches (FFB) transported from farmgate to mill, and grown by smallholders or large-scale plantations. Current leverage on 'illegal' palm oil may primarily come from making mills responsible for their source areas. However, it is not clear whether these efforts mostly lead to 'shifting blame' $[29,30]$ or whether they actually contribute to changing land-use and effectively protecting forests.

While uncertainty over the exact numbers and locations on FZ-OP continues, we set out to formulate lessons from earlier interactions between forest authorities and the other tree crops (coffee, cocoa, rubber) and to contextualize and analyze policy options and how these might be applied to the various contexts that contribute to the overall issue. We will review the available data and literature on:

- The history of forest legality and oil palm expansion in Indonesia as context for current forest-related issues of local land use versus designation of the land as part of the forest zone;

- Spatial analysis of FZ-OP at the intersection of forests and tree crops for Indonesia as a whole and zoomed in on two provinces with higher-resolution data;

- Social and economic concerns on oil palm expansion and the role of smallholders in FZ-OP;

- Environmental concerns on tree crops in relation to the primary designated forest function in (A) production forest (income generation), (B) protection forest (watershed protection) and (C) Conservation areas (Biodiversity);

- Policy options linked to forest-related contexts, informed by the responses of various stakeholders along the palm-oil value chain to FZ-OP.

We conclude by formulating more specific policy research questions as a follow-up. 


\section{Methods}

\subsection{Literature Review}

Starting from several recent reviews of oil palm in Indonesia, we used a 'snowball' method to identify more recent papers citing these sources and followed up on the citation network thus established to document a synthetic view on the various sub-topics.

\subsection{Maps}

For a more detailed analysis of the different forest designations within the forest zone and for the time frames of expansion within the forest zone, we compiled data for Jambi, a province in Sumatra around the Equator, and West-Kalimantan. The two provinces were selected to represent the two islands where oil palm is major (Sumatra and Kalimantan) while they had different historical settings on traditional land use of agroforest and its dynamics. Availability of the data also determined the choice of the two provinces. We traced the development of oil palm and agroforestry areas in the 2000-2020 period in each of the Forest-zone categories and sought the trajectories of changes and observed interlinks between oil palm, forest and agroforestry. Where the data were available, we incorporated the other major agroforestry tree-crops; otherwise, we utilized the common class of 'mixed agricultural tree-crops' mapped in most datasets. The following dataset was utilized for the analyses (Table 1).

Table 1. Maps utilized for case studies.

\begin{tabular}{|c|c|c|c|c|}
\hline No & Map Title & Year (s) & Extracted Class (es) & Source \\
\hline 1 & $\begin{array}{l}\text { Peta Penutupan Lahan Indonesia } \\
\text { (Indonesia Land Cover Map) }\end{array}$ & 2000, 2009, 2018 & Agroforest & {$[31]$} \\
\hline 2 & Ecological Vegetation Map of West Kalimantan & 2019 & $\begin{array}{c}\text { Agroforest } \\
\text { Rubber plantations } \\
\text { Oil palm plantations } \\
\end{array}$ & [32] \\
\hline 3 & $\begin{array}{l}\text { Global map of smallholder and industrial } \\
\text { closed canopy oil palm plantations }\end{array}$ & 2019 & $\begin{array}{l}\text { Oil palm plantations } \\
\text { Independent smallholder } \\
\text { oil palm }\end{array}$ & [33] \\
\hline 4 & National Main Commodity Maps in Indonesia & 2019 & $\begin{array}{l}\text { Oil palm } \\
\text { Rubber }\end{array}$ & [28] \\
\hline 5 & $\begin{array}{c}\text { Kawasan hutan Provinsi Kalimantan Barat } \\
\text { (Forest-zone Lands of } \\
\text { West Kalimantan Province) }\end{array}$ & 2014 & & [34] \\
\hline 6 & $\begin{array}{l}\text { Kawasan hutan Provinsi Jambi } \\
\text { (Forest-zone Lands of Jambi Province) }\end{array}$ & 2014 & & [35] \\
\hline
\end{tabular}

\subsection{Public Consultation}

In a webinar in September 2020, attended by 374 participants, the issue of overlap between Indonesian forest estate and oil palm was highlighted and a number of the basic data presented; the questions and discussions formed the start of this manuscript. Specific aspects discussed are listed in Appendix A at the end of this manuscript.

\section{Indonesian Context}

\subsection{Forest Legality}

While efforts to agree on a forestry law during the Colonial period stranded [36], the postindependence (1945) constitution clarified that all the country's resources were for the benefit of the Indonesian people-with subsequent debate on the degree to which the Government of Indonesia has to respect prior claims of customary communities ('Masyarakat Hukum Adat') [37]. The Basic Agrarian Law of 1960 that recognizes colonial period documents as a basis for valid rights to land and the Forestry Law of 1967 was considered to be complementary but had gaps between them [38]. The 1999 revision of the 
Forestry Law specified that state ownership claims within the designated 'forest zone' ('Kawasan Hutan') required completion of a gazettement procedure (verifying that there are no valid pre-existing claims), which has been very slow to implement [39], leaving doubts on the legality of government forestry policies that treat the Forest-zone as government-owned.

The total area of forest-zone lands in Indonesia (63\% of total land area) is subdivided by primary function, as 'Production Forest' (68.8 M ha; $36.1 \%$ of the country), 'Protection Forest' (29.7 M ha; $15.6 \%$ of the country) and 'Conservation Areas' (22.1 M ha; $1.6 \%$ of the country) [40]. Logging is only allowed in the production forests, with further restrictions in part of the zone, and conversion to monocultural plantations for the pulp and paper industry in other parts. Although logging-based economic interests prevail in this zone, the production forests still have a recognized role in biodiversity conservation, carbon storage and maintenance of watershed functions. Most of the Protection Forest (the Indonesian term could also indicate '(watershed) protecting' forests) are on mineral soils and have been defined through a scoring system emphasizing slope and similar criteria for soil and water protection. For peatland areas, there are separate criteria for determining a Protection Function ('Fungsi Lindung') indication, based on peat depth and the peatland moratorium policy [41]. The total area of Protection Function in Indonesia's peatlands is $12.3 \mathrm{M}$ ha [42].

Building on the specific example of the damar agroforests in Krui (West Lampung, Sumatra) where government ownership claims to forest-like vegetation could not be substantiated [43,44], it was realized that 'agroforests', of various specific histories and intensities of management, were included in the Forest-zone, either with Production or Protection Forest designations, but also claimed by local communities as existing before the Forestry law was formalized [45]. Since then, a government commitment to 'community-based forest management' and 'village forests' has allowed some conflict zones to be resolved, but much remains to be done [46,47]. Meanwhile, calls to redefine the Indonesian forest estate and get the boundaries of its Forestry Regulatory Framework and Agrarian rules right [12,48-51] were largely unheeded. Global interest in and country-level expectations of, new financing mechanisms through Reducing Emissions from Deforestation and (forest) Degradation $($ REDD + ) created a new dynamic where issues of 'forest legality' obtained new relevance [52,53]. Indonesia's challenge to balance the new global environmental agenda on forest conservation, with the existing development deficits is part of a wider global pattern [54].

\subsection{Complexity of Frontier Situation}

In Southeast Asia's long engagement with global markets, cocoa, coffee, fast-growing trees, oil palm, rubber and shrimp have all had periods of rapid expansion or 'booms' when the region proved to be a low-cost producer in which land, labor, know-how, and market access could be rapidly mobilized [55]. The 'land grab' literature tries to answer key questions on who seeks to exercise control over land to grow export-oriented crops under boom conditions, how would-be producers navigate regulatory powers and market forces to gain control over land, and how booms differentially affect areas with secure and insecure land control relations.

Since the 19th century, commodities such as rubber [56], coffee [57] and cocoa [58] have boomed in specific parts of Indonesia, creating new 'forest frontier' conditions, involving local people, attracting investors to come in, but also stimulating people from other location to move in, spontaneously and/or in government-sponsored transmigration [59]. The relationships between spontaneous migrants, large-scale plantation companies, local communities and various branches of government have become complex in many locations [60-63]. Due to its location, boom crop production is closely associated with the issue of deforestation and environmental degradation [64].

Indigenous people and local communities (jointly described here as IP/LC) in forest frontier areas have had a long tradition of a 'dual economy' [65] where food security continued to depend on swiddening, while cash-crop agroforestry (rubber, coffee, resin trees and now oil palm) provided a financial basis for their livelihoods [66]. Where the terms of trade were sufficiently favorable, staple food production could be 'outsourced' [67]. Accordingly, most of the oil palm grown by IP/LC, 
just not to say smallholders, has not been a direct cause of deforestation as they developed in a village environment of orchards, old rubber groves and swidden fallows. Smallholders also tend to use fertilizer sparingly, as they are unable to access subsidized fertilizer supplies that are monopolized by larger plantations [68].

While global policies and markets are often held responsible for accelerated deforestation in the tropics [69], local knowledge is generally assumed to lead to overall positive outcomes in matters of conservation [70,71]. Even in matters of primary forest conversion, local communities are usually presented as the best managers to reconcile conservation and development [69]. Increased attention for forest protection in the context of REDD+ may have increased pressure on converting agroforests outside the forest zone to become oil palm monocultures [72].

The Indonesian forest frontier is home to approximately 26 thousand villages (often defined as 'forest villages') and more than $37 \mathrm{M}$ peoples, with some $18 \%$ still struggling to escape from poverty based on the national standard [73]. Most of the forest villages are also not formally registered yet, as nationally only $30 \%$ of villages are already registered, mostly in Java. They have no clear and defined boundary and are dominated by state forest land, with formal restrictions to use for crops to generate food or income. In such landscapes, boom crop production, such as oil palm, has taken place. Expansion of agriculture into the forest area, often following onto a logging phase that brought people and road access (however poor) into the forest zone, is considered because of these complexities, that for decades have remained unresolved.

\subsection{Total Oil Palm Area}

According to the most recent official figure, the oil palm area in Indonesia was 14.7 M ha in 2019 [74]. Several organizations have also mapped oil palm areas for different objectives and with a range of methods (Table 2). Bahktiar et al. [75] claimed a substantially larger area (16.8 M ha), by including areas cleared for oil palm but without stands recognizable by remote sensing yet. The lowest recent estimate was 11,530,000 ha [33], in a study that only included fully-developed stands. Time-series data of oil palm for Borneo were analyzed for forest loss or deforestation [76] and biodiversity impacts [77]. The breakdowns of oil palm areas varied, with one study differentiating 'industrial' and 'smallholder' oil palm [33], while another study [75] focused on oil palm areas within forest zone lands. Condro et al. [28] mapped major commodities including coffee and cacao, and obtained area estimates close to the data from the Ministry of Agriculture. Across Indonesia, the largest oil palm areas are in Sumatra and the second largest in Kalimantan, covering respectively $6.4 \mathrm{M}$ ha and $4.9 \mathrm{M}$ ha in 2018 [74], while another study [75] mentioned 10.5 $\mathrm{M}$ ha and 5.7 $\mathrm{M}$ ha, respectively, for these two islands. Oil palm is expanding in W and SE Sulawesi, and in Papua, but current areas remain relatively small.

Table 2. Published estimates of the total area of oil palm in Indonesia.

\begin{tabular}{|c|c|c|c|c|c|}
\hline No & Oil Palm Hectarage & Year & Approach and Methods & Notes & Reference \\
\hline 1 & $16,800,000$ & 2015-2017 & Multi-data analyses & $\begin{array}{l}\text { Including unplanted area for industrial oil } \\
\text { palm within forest zone }\end{array}$ & [75] \\
\hline 2 & $14,896,964$ & 2019 & $\begin{array}{l}\text { Automatic classification using } \\
\text { multi-data in GEE }\end{array}$ & $\begin{array}{c}\text { RS methods; } \\
\text { Oil palm and other major commodities }\end{array}$ & [28] \\
\hline 3 & $14,724,420$ & 2019 & $\begin{array}{l}\text { Using trade statistics and } \\
\text { yield data as a basis }\end{array}$ & $\begin{array}{l}\text { Official Oil Palm statistics; industrial } \\
\text { (private and state) and smallholders }\end{array}$ & [74] \\
\hline 4 & $11,530,000$ & 2019 & $\begin{array}{l}\text { Automatic classification of } \\
\text { sentinel imageries with NN }\end{array}$ & $\begin{array}{l}\text { RS methods; } \\
\text { Differentiation of industrial } \\
\text { and smallholders }\end{array}$ & [33] \\
\hline 5 & $11,100,000$ & 2015-2017 & $\begin{array}{l}\text { Visual interpretation of } \\
\text { Landsat imageries }\end{array}$ & Oil palm and deforestation & [78] \\
\hline
\end{tabular}

The distribution of oil palm in Indonesia is uneven and strongly related to climatic conditions. In North Sumatra (Figure 2A), the province with the most even rainfall distribution and virtually 
no dry season oil palm can reach up to $50 \%$ of the area at district (Kabupaten) level; elsewhere in lowland Sumatra and the southern half of Kalimantan it can reach up to $30 \%$ of the area, but in most of Indonesia, oil palm forms less than $10 \%$ of the landscape or is virtually absent. For Indonesia as a whole oil palm covers about $8 \%$ of the total land area. The fraction of oil palm under smallholder ownership (see below for the distinctions within this category) is approaching 50\% for Sumatra, but half of that in most of Kalimantan (Figure 2B). The recent expansion of oil palm, indicated by relatively young stands, is evident outside of the areas that already have a large oil palm fraction (Figure 2C).

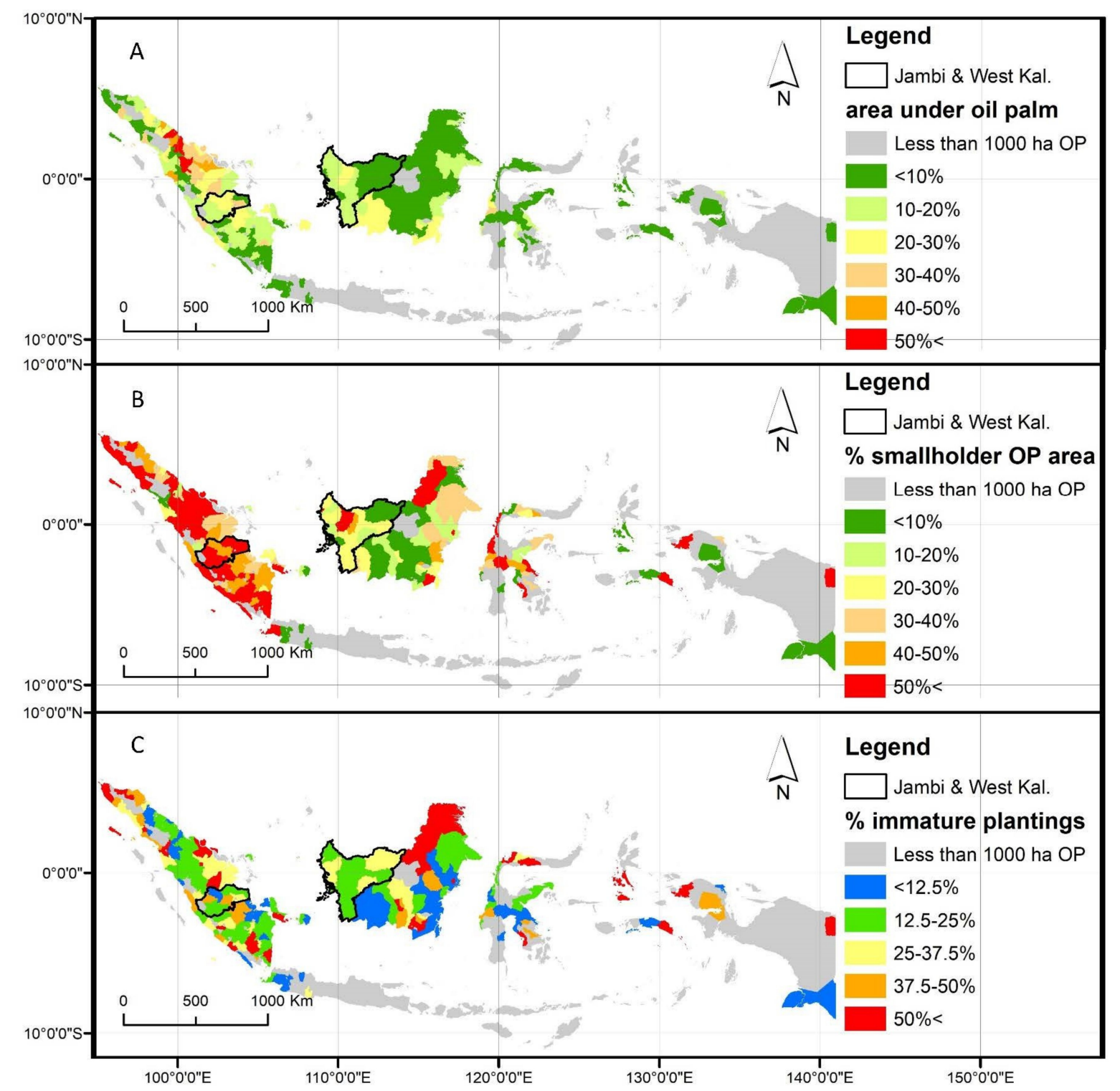

Figure 2. Maps on 2017 oil palm distribution at the district level in Indonesia, highlighting Jambi and West Kalimantan provinces; (A) Area fraction under oil palm; (B) Share of oil palm cultivated by smallholders; (C) Share of oil palm that does not yield yet as it is too young (usually less than three years old); Sources: Own maps, oil palm data from [79]; district boundary and area data from [80].

Several authors have quantified oil palm development within the forest zone in Indonesia [76,78]. Estimates vary from 2.5 [76] to $3.4 \mathrm{M}$ ha [75]. This implies that $15-20 \%$ of Indonesian oil palms grow within the designated forest zone. The dataset of [75] allows some further exploration of the geographical patterns of Indonesia's Forest-zone oil palm (FZ-OP). The relative share in Indonesia's FZ-OP at the province level does not match shares in total oil palm production. With $31.5 \%$ of 
Indonesian oil palm, the two provinces of Riau + C Kalimantan have 66.8\% of its FZ-OP (Riau 20.7\% OP, $42.1 \%$ of FZ-OP; C. Kalimantan $10.9 \%$ of OP and $24.7 \%$ of FZ-OP). With $41.2 \%$ of Indonesian OP, the rest of Sumatra has $24.0 \%$ of its FZ-OP; with $23.7 \%$ of Indonesian OP, the rest of Kalimantan has $7.7 \%$ of its FZ-OP and with $3.6 \%$ of Indonesian OP, Eastern Indonesia + Java have 1.4\% of its FZ-OP. Across Indonesia, $2.96 \%$ of FZ-OP is designated as conservation area, $4.71 \%$ as (watershed) protection forest, $15.15 \%$ as production forest with restrictions, $45.4 \%$ as regular production forest, and $34.8 \%$ as production forest indicated for conversion. The total area of FZ-OP is 2.88 times the amount of production forest indicated as 'conversion forest' (planned, legal deforestation).

For further exploration of that pattern as well as to showcase the development of oil palm gardens as part of agroforestry pathways, we focused on two provinces, one each in Sumatra (Jambi ranked \#7 in oil palm production and \#5 in FZ-OP) and Kalimantan (W. Kalimantan, ranked \#3 in oil palm production and \#6 in FZ-OP). Both are outside the historical oil palm core area in N. Sumatra, but they were part of the expansion since the 1990s; the district-level presence of oil palm within these provinces varies from 0-30\%. The two provinces have harmonized their Kawasan Hutan areas with the provincial planning (RTRWP) with ministerial decrees that legalized the status of 'Forest-zone lands.' Therefore, issues of agroforest and oil palm practices in these two provinces are not burdened by different interpretations of forest legality between the central government (MoEF) and the provincial governments.

\section{Oil Palm in the Forest Zones of West Kalimantan and Jambi}

\subsection{Data by Province and Forest Category}

The total area of Forest-zone lands, encompassing all Conservation Areas (National Park and forest reserves), Protection Forest and all Production Forest status (HP, HPT, HPK) in West Kalimantan is $8.1 \mathrm{M}$ ha or $56 \%$ of the province area, while for Jambi it is $2 \mathrm{M}$ ha or $43 \%$ of the province.

For West Kalimantan, agroforest area occupied 38\% of all Production Forest status and 16\% of Protection Forest areas [31], while according to [32], agroforest covered $<10 \%$ (Table 3). Some of the agroforests in [32] are mapped by [31] as disturbed forest, and that was the main differentiating factor of forest and agroforest areas in the two maps. Major commodities of oil palm and rubber are negligible in West Kalimantan's Forest-zone lands, the highest being oil palm in Production Forest areas (4\%) mapped by [28].

Table 3. Areas of agroforest and major tree crops in West Kalimantan and Jambi in 2018-2019.

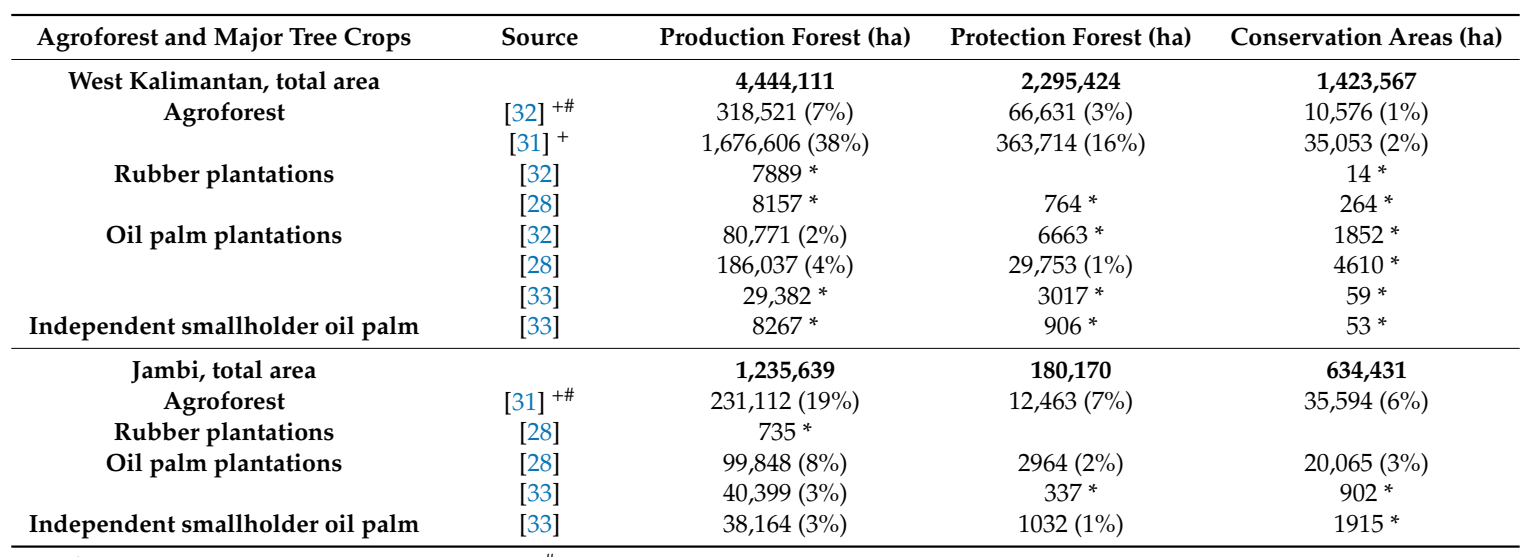

${ }^{+}$processed/reclassified for this paper, ${ }^{\#}$ utilized for further analyses, ${ }^{*}$ percentage lower than $1 \%$ of the respective forest-zone land category.

In Jambi, agroforest occupied $19 \%$ of the land with Production Forest status, and $<10 \%$ for Protection Forest and Conservation Areas [31] (Table 3). Rubber and oil palm monocultures were $<10 \%$ in all Forest-zone land categories in Jambi [28,33]. A breakdown of FZ-OP by elevation and forest category (Figure A1) shows most are below $100 \mathrm{~m}$ above sea level. 
Taking the total amount of palm oil produced in each of the provinces as point of references, the likely source areas differ between the two provinces, and according to three data sources specified in Table 4, with 6-17\% derived from the forest zone. Within the forest zone, the fractions derived from production forest are highest (even after correction for the total area), followed by protection forest and conservation areas.

Table 4. Likely source area of palm oil produced in West Kalimantan and Jambi according to three spatial data sources, expressed as \%, assuming homogenous productivity per unit land.

\begin{tabular}{cccccc}
\hline Province & \multicolumn{3}{c}{ West Kalimantan } & \multicolumn{2}{c}{ Jambi } \\
Data Source & [75] & [33] & [28] & [33] & [28] \\
\hline Non-forest land & 93.65 & 96.30 & 89.93 & 89.05 & 83.05 \\
Production forest & 5.70 & 3.30 & 8.44 & 10.40 & 13.78 \\
Protection forest & 0.47 & 0.34 & 1.35 & 0.18 & 0.41 \\
Conservation areas & 0.13 & 0.01 & 0.20 & 0.37 & 2.77 \\
\hline
\end{tabular}

\subsection{Data by Time Period—Land Cover Changes Involving Agroforest and Smallholder Oil Palm}

Agroforest in West Kalimantan was mostly as rubber gardens and tembawang (Dayak traditional land-use system) having been practiced for generations [81,82]. Inside the Forest-zone lands in West Kalimantan, the majority (76\%) of 300,000 ha agroforest areas in 2019 was already agroforest in 2000, and only $11 \%$ was forest (Figure 3)

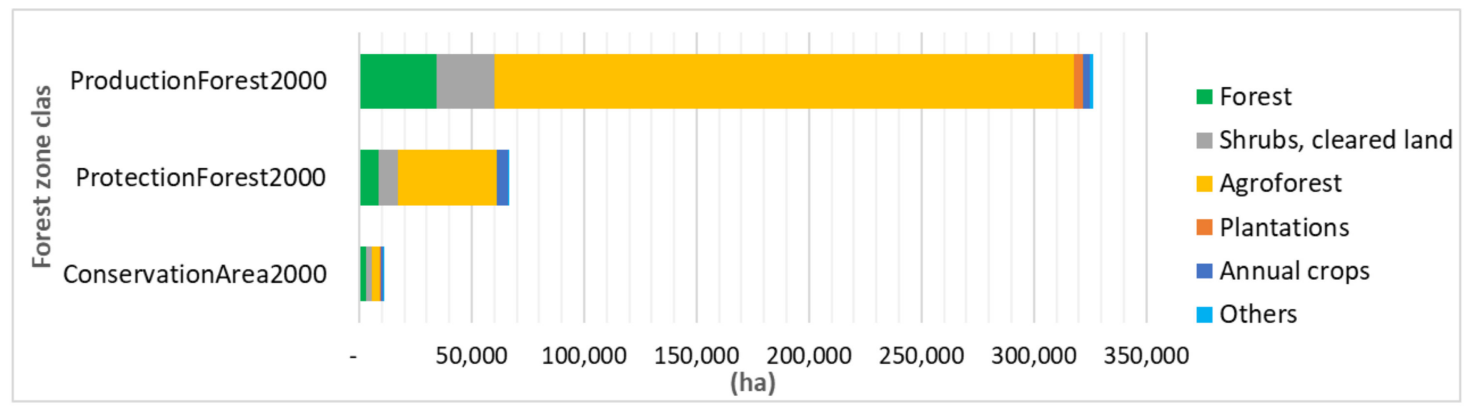

Figure 3. Land cover trajectory (2000) of 2019 agroforest in each Forest-zone class in West Kalimantan (analyzed from [31,32]).

The development of independent smallholder oil palm was closely linked to the conversions of the locally managed agroforest areas due to the lucrative oil palm market in the vicinity of the villages and the decreasing popularity of rubber due to its volatile price [82]. That trend is observed in the land cover trajectory of independent smallholder areas in West Kalimantan, i.e., $57 \%$ of which was agroforest in 2000 and 54\% in 2009 (Figure 4). Only 13\% and 6\% of independent oil palm was a forest in 2000 and in 2009, respectively.

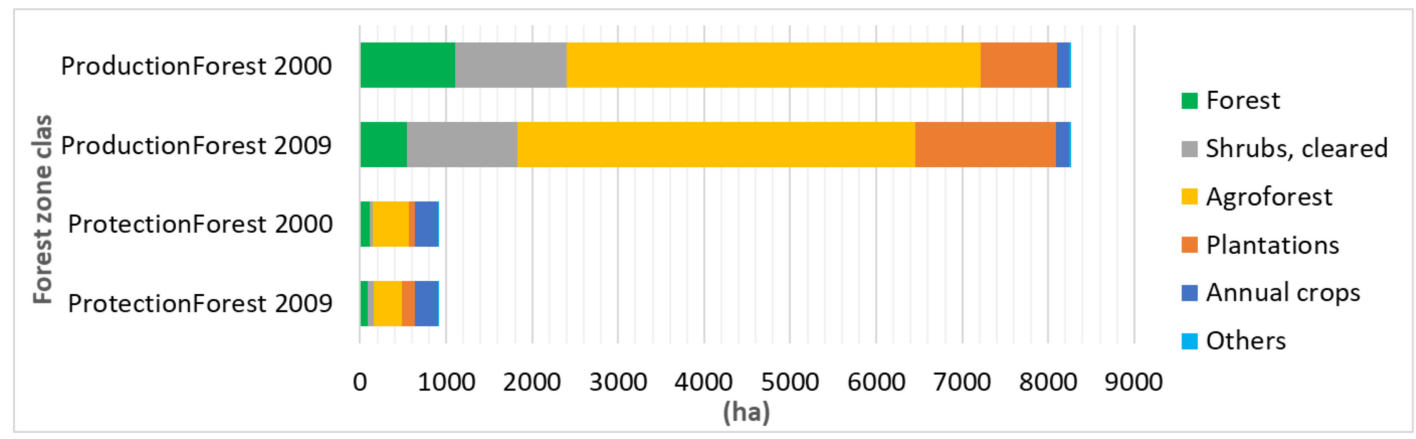

Figure 4. Land cover trajectories (2000 and 2009) of 2019 independent smallholder oil palm in each Forest-zone class in West Kalimantan (based on [31,33]). 
For Jambi, agroforest was originally developed by local communities with rubber as the major crop introduced in the beginning of the 1900 s during the Dutch period $[56,82,83]$. It dominated private lands (APL), but its growth reached the areas designated as Forest-zone lands. The 2018 agroforest in Jambi's Forest-zone lands was equally agroforest (44\%) and forest (44\%) in 2000 (Figure 5), proving the historical presence of this locally managed land use in state's lands.

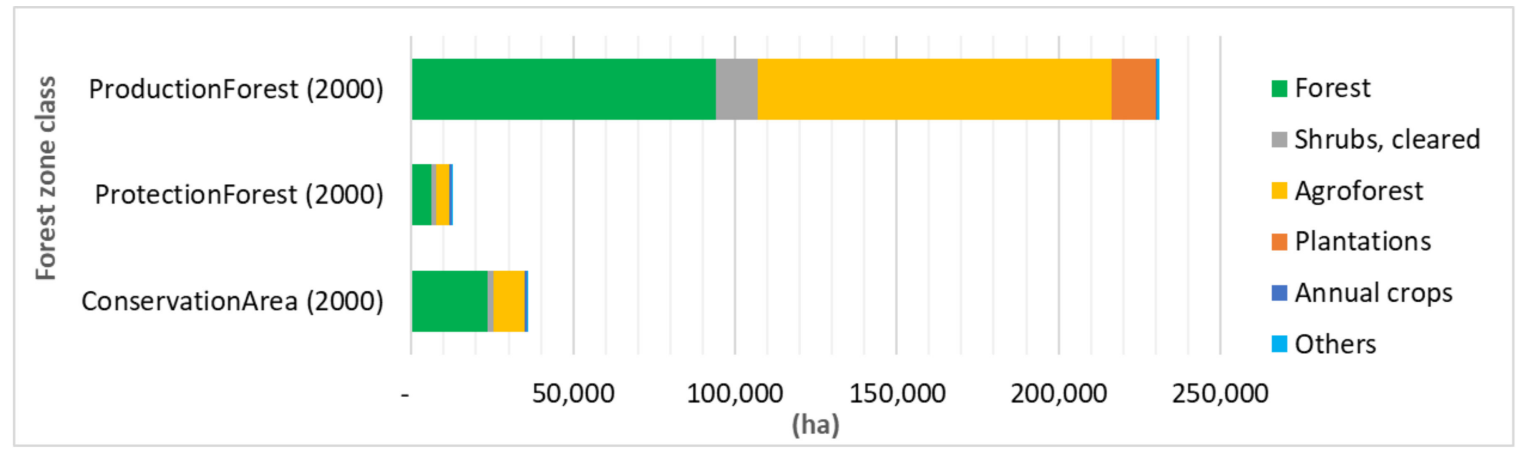

Figure 5. Past land cover types of agroforest in Forest-zone lands in Jambi (analyzed from [31]).

Expectations of high profitability of conversion to oil palm attracted many agroforest rubber farmers in Jambi, also signifying the changes from food sufficiency to cash-cropping [84], in addition to the volatile price mentioned earlier. Independent smallholder oil palm in Jambi's Forest-zone lands was 39\% agroforest and 15\% plantations in 2009, while in 2000 it was $11 \%$ agroforest and $21 \%$ plantations (Figure 6). These demonstrate the development of independent smallholder oil palm in Forest zone lands involving agroforest and plantations, mostly rubber. Growth of oil palm also reached degraded areas, shown by 15\% shrubs in 2000 and 34\% in 2009 (Figure 6), which included peatlands in the lowland areas $[85,86]$.

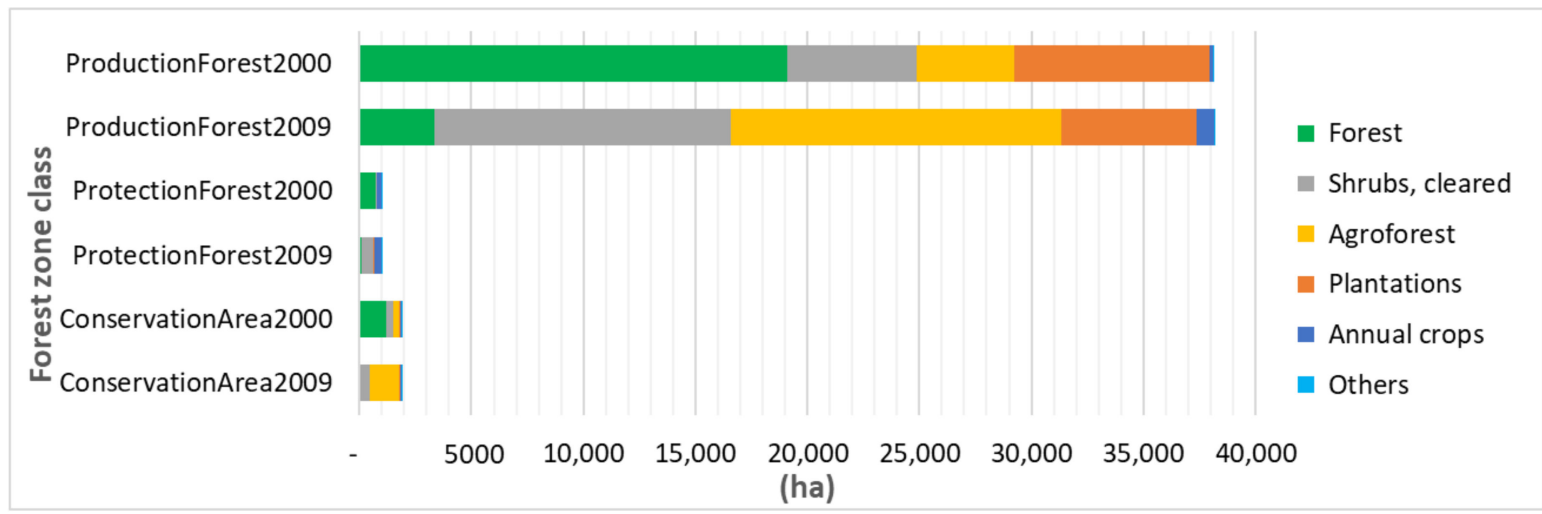

Figure 6. Land cover trajectories (2000 and 2009) of 2019 independent smallholder oil palm in each Forest-zone class in Jambi (based on $[31,33]$ ).

Agroforest that has long been managed by local communities has evolved in Forest-zone lands, with the highest proportions and areas in Production Forest status (Figures 4 and 6). With the long history, this land use had faced unresolved forest zone issues since before the 1999 Forestry Law (see Section 3.1) until now, under the Kawasan Hutan officiated in 2014 for the two provinces. Since the past decade, oil palm has emerged to become part of the dynamics of this local farming, including in Forest-zone lands. The data show that these dynamics mostly occupied the Production Forest status (Table 3), the class allocated to support various production functions. Looking at the 'predecessor' cash-crop of rubber as part of the ever-evolving mixed-crop agroforest land use [56,81,82], independent oil palm might grow similarly, spatially and or temporally, as part of community-based production functions in land with Production Forest status. 


\section{Social Dimensions}

\subsection{Overview Indonesian Oil Palm Sector}

The palm oil value chain has a distinct hourglass shape (Figure 7). Upstream there are vast conglomerates that own plantations covering hundreds of thousands of hectares and may be involved in all stages of the value chain. At the other extreme are millions of smallholders that own only a small plot and sell their produce at the farmgate. In between are many shades of grey, ranging from smaller groups, independent large-scale plantations, investors owning a hundred hectares, farmer groups and independent farmers who accumulated multiple small plots over time. Their produce is eventually processed in just over 1000 mills [87], subsequently sold to a few dozen refinery companies, which subsequently supply a few trading companies, that sell their products to a vast number of stakeholders as consumer goods companies and retailers [88].

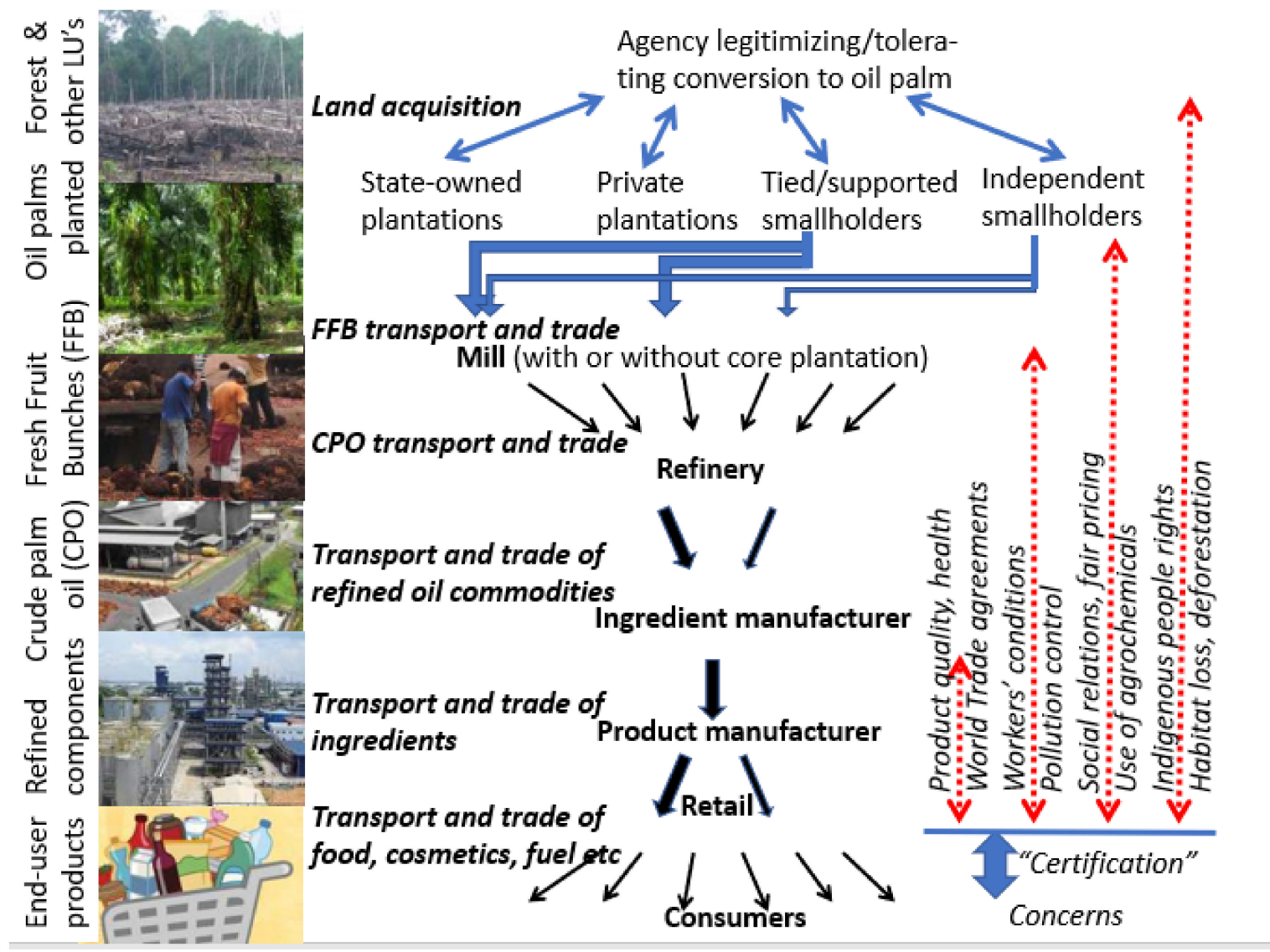

Figure 7. Schematic structure of the oil palm value chain [26].

\subsection{Heterogeneity and Expansion amongst Oil Palm Smallholders}

Starting on Sumatra's east coast plantation belt, oil palm has been cultivated commercially in Indonesia since 1911 [89]. Smallholders, however, were not involved in oil palm cultivation till the late 1970s, when the New Order regime assigned State-owned plantation companies to develop oil palm plantations that included smallholder farmers. This policy was directed to support the socio-economic development of new settlers and local people in Indonesia's outer islands ${ }^{1}$ and develop export commodities that reduce dependency on mineral oil exports. Whereas smallholders first appeared

1 Outer islands usually refer to islands beyond densely populated Java, Madura and Bali islands. 
in oil palm statistics in 1979, covering a mere 3125 ha [90], by 2018 their area covered an estimated 5.8 million hectares, which is equivalent to $40.6 \%$ of Indonesia's palm oil area [79]. Whereas oil palm smallholders are often categorized in national statistics as a single entity it is increasingly clear that this vast sub-sector is highly heterogeneous and there is a need for targeted policy measures to improve the environmental and socio-economic performance of the different types of smallholders [91,92]. A key differentiation amongst oil palm smallholders is the scheme vs. independent smallholder dichotomy $[93,94]$.

Scheme smallholder plantations, often also referred to as plasma or 'kemitraan', are smallholder plantations that have been developed by a plantation company and usually involve company credit for plantation establishment and other agro-inputs, knowledge sharing, and a take-off agreement between smallholders and partner company. Smallholders are usually allocated 2-3 hectares [95]. However, partnership agreements can be highly diverse depending on the regulatory framework present at the time of partnership development, and the negotiations between stakeholders $[95,96]$. For example, early schemes allocated $60-80 \%$ of the plantation to smallholders, but under the influence of World Bank policies and to accommodate private sector investments, this shifted to $40 \%$ for smallholders in the late 1980s and 1990s [97,98]. In 2007 the new plantation law stipulated that companies needed to allocate $20 \%$ of their concession to smallholders within their concession boundary, and in 2013 this was changed to $20 \%$ for smallholders with land possibly outside the company concession [68]. Many companies do not reach this target, however, and this requirement may well be deleted in the new 'omnibus' law that Indonesia is currently preparing [99].

Whilst in some partnerships smallholders are strongly involved in plantation management decisions, participate in plantation labor, and may even outperform their partner company in terms of yields [100], in other arrangements smallholder plantations are fully managed by the company. This last category is often referred to as one-roof management, in which smallholders are effectively mere shareholders $[96,101]$. Whereas production levels in schemes are generally close to company plantations and thus relatively high for smallholder producers, such schemes frequently suffer transparency issues and especially beneficial to companies $[68,102]$. Over time government policy regarding oil palm smallholders has increasingly shifted from being a poverty reduction strategy towards one that strengthens industry interests and requires minimal government investments.

Independent oil palm smallholders quickly emerged once the benefits of oil palm cultivation by scheme farmers became obvious. Mills started buying produce outside their plasma and own plantations, and basic infrastructure developed by logging, plantation, and mineral oil companies opened up lands that were previously uneconomic to develop [103,104]. Findings from Jambi indicate that direct economic profits of independent oil palm plantations were significantly higher than forests [105]. Also, oil palm demands less labor compared to competitor cash-crops as rubber, thus allowing for more land to be cultivated or freeing time to engage in other economic activities [106,107]. Independent smallholders generally have no direct links to mills and do not receive extension services from the government or companies. Subsequently, independent smallholders generally have limited knowledge of good agricultural practices, use poor planting material, apply minimal and unbalanced fertilizer regimes, receive low prices for their produce, and suffer yields well below companies and plasma farmers [96,108,109].

The independent oil palm smallholder sector is highly heterogeneous, with many different layers in society engaging in smallholder oil palm development. The independent oil palm smallholders sector includes small local farmers with a few dozen oil palms, migrants attracted by cheap land, oil palm company employees investing in nearby land, local government officials and shop owners looking for investment opportunities and purchasing 5-10 ha, local or urban elites that engage in semi-corporate oil palm plantations and everything in between [93,101]. Multiple typologies on independent oil palm smallholders in Indonesia have been developed [93,101,110], showing presence and ratios between types of smallholders differ in different landscapes. For example, remote peat frontiers often involve relatively large investors whilst transmigration areas or traditionally relatively 
densely populated areas have a relatively large share of smaller farmers that converted their traditional land uses [93,101].

Whereas land rights and land ownership documentation are generally well arranged in plasma, this is often not the case amongst independent oil palm smallholders [93]. Krishna et al. [111] suggested that especially indigenous populations can obtain forested land and develop oil palm or cash crops in the forestry domain, but sales of such land are limited as it is undervalued due to lack of marketability. Although migrants often do not have nationally recognized land ownership, they require more security in land titles and pay higher prices for land. These authors [111] therefore warn that land titling programs may well lead to the increasing value of land, indigenous people selling their land, claiming new land, and thereby triggering new deforestation [112]. Purnomo et al. [113] provide a detailed analysis of the stakeholders involved in the conversion of land into independent smallholder oil palm plantations in Riau and highlight the considerable profits that accrue to those involved at different stages of the land conversion, including the land mafia. It is increasingly clear that the diversity amongst smallholders and the different landscapes in which they operate needs to be acknowledged for developing adequate policies that foster more sustainable landscapes.

Although reliable current data on plasma vs. independent smallholder are not available, smallholders in plasma schemes were numerically overtaken in 2005 by 'independent' smallholders (including those in various partnership schemes) [114]. Since then some existing plasma plantations have transformed into 'independent' smallholder plantations and oil palm sector growth rates between 2015 and 2018 show that private sector large-scale oil palm plantations grew by 1.91 million ha and that smallholder oil palm area increased by 1.28 million ha [79]. If companies meet their plasma obligations, this would mean a 382,345 ha increase in plasma area and a 901,143 ha increase in independent smallholder area, highlighting that it is especially the independent smallholder sector that is expanding. Whereas companies and associated plasma smallholdings are relatively easy to identify, monitor, and sanction due to the size of their plantations and relative ease of targeting managements, this is not the case with independent smallholders. These independent smallholders are huge in the number of management units that occupy relatively small areas, making it highly complex to manage independent smallholder oil palm expansion. With limited external support and little monitoring, the independent smallholder oil palm has developed into a cheap buffer for the industry; this relates to setting sustainability standards as well as organizing a supply chain.

\section{Ecological Dimensions}

The economic benefits of oil palm production reviewed above have been discussed in tradeoff with negative impacts on ecosystem services [25,115-117]. However, specific issues of FZ-OP have not been discussed as such in the literature we reviewed. Oil palm cultivation, but especially its continued expansion, has led to severe negative effects on environmental quality such as biodiversity depletion [118,119], loss of hydrological function [118,120-123], increased carbon emissions [85,124], and reduction of water and soil quality $[116,118,121,125,126]$. The magnitude, and sometimes the sign, of the changes in ecosystem service levels, depend on what land cover is compared to oil palm, and to a smaller extent on the specific way oil palm is grown. Where conversion of natural forest to oil palm represents a drastic change in conditions, comparison of oil palm with the monocultures of fast-growing timber for the pulp- and paper industry, a legal change within production forest, may come out in favor of oil palm in several ecological dimensions. Although the Indonesian rules for logging in the production forest were supposed to secure sustainability across multiple harvest and recovery cycles, there are very few examples where such has been actually achieved in the reality of social-ecological systems.

\subsection{Biodiversity}

The conversion of natural forests to oil palm plantations threatens biodiversity according to many authors [115,127-129]. Forest fragmentation and large-scale homogenization landscape, whether for the 
development of plantation forestry or oil palm, pose a serious threat to tropical biodiversity $[118,130,131]$, reducing species richness $[128,132,133]$ and leading to a strongly declined functional diversity $[134,135]$. However, the response of biodiversity to land-cover change depends upon the extent to which natural habitat features are replicated while the sensitivity of species to change varies [130].

Several global studies have highlighted that past and predicted expansion of oil palm plantations into forest areas threatens mammal [136] and bird species with extinction [134,137,138]. In Indonesia, both Sumatran and Bornean orangutans (Pongo abelii, P. pygmaeus) and proboscis monkeys (Nasalis larvatus) population trends are decreasing due to the expansion of large-scale oil palm plantations [139-144]. Herds of elephants, tigers and rhinos are reported to be critically threatened due to this expansion $[137,145]$. In peat swamp forests, the expansion of oil palm monocultures is likely to have negative effects on, among others, macrofungal biodiversity [146].

A study [131] quantifying the impact on the herpetofauna of the Pacific lowlands of Costa Rica found that total species richness of amphibians and reptiles was reduced to $45-49 \%$ compared to forest area due to the almost complete absence of leaf litter, understory vegetation, and woody debris and the more open canopy. However, different research [147] conducted in Sumatra (Indonesia) showed different results. Rare amphibians were much more abundant in riparian forests and common amphibians were more prevalent in oil palm plantations. Indeed, reptile richness and abundance were higher in oil palm plantations than in all other habitats. Surprisingly, a meta-analysis [137] found that average invertebrate species richness did not differ significantly between oil palm and forest sites when published studies were compiled. It is commonly found that different aspects of biodiversity are influenced in opposite ways during land-use change [148].

Protection of any forested habitats and enhancing understory vegetation can help improve opportunities for some species [131]. Forest patches, even when small, fragmented and degraded, i.e., riparian sites, doubtlessly are required to sustain the species in human-transformed landscapes $[139,146]$. Substantial biodiversity loss can only be avoided if future oil palm expansion is managed by avoiding deforestation and cultivating non-forested and abandoned areas for sustainable oil palm cultivation $[78,143,149]$. The small-scale oil palm production due to greater vegetation heterogeneity is also likely to provide greater ecosystem services provision and should be considered as one of the strategies for achieving sustainable oil palm production [150]. By reducing deforestation and ecosystem degradation, stopping land clearing techniques by land burning, and stopping the development of oil palm plantations on unsuitable land, sustainable palm oil management can be achieved [120].

\subsection{Watershed Functions}

Oil Palm plantations are known to alter the hydrology of the subwatersheds in which they develop, by increasing the risk of flooding, increasing soil erosion (especially in the planting phase) and nutrient leaching, polluting ground- and surface water [124]. Once established, oil palm-dominated landscapes are 'water greedy' [122], responsible for decreasing local water tables and water supplies as well as changes in streamflow levels and water quality $[118,122,151]$. Several studies reported that the conversion of forests to young plantations initially decreased evapotranspiration (ET), but also decreased infiltration rates [122,124]. Researchers in Brazil [152] reported that water shortages have occurred more often since oil palm cultivation has become the dominant land use and large-scale deforestation has taken place. A study of land-use change impact on flooding frequency in Batanghari Watershed, Indonesia, showed that land cover change from forest to rubber and oil palm plantation contribute to the higher flooding frequency [153].

Though water availability, air, and water quality were perceived to be the most heavily impacted ecosystem services by oil palms [151], there is a knowledge gap about the magnitude of these ecohydrological changes and their variations over the oil palms lifetime [118,123]. It is unclear whether young and mature plantations have similar or different ET rates when compared to native forests $[118,123]$. The impacts of oil palm on the major components of the hydrological 
cycle (e.g., total water yields, dry season baseflow, streamflow dynamics, evaporative return to the atmosphere) are still at an early stage [118,121,152,154,155].

The constraint is that in general, countries with large oil palm plantations are developing countries with limited resources to assess the impact of plantations throughout the growing period of oil palm on hydrological functions [119]. Moreover, oil palm plantations are generally homogeneous monoculture stands of various age classes, with varying water use characteristics [154]. Most of the hydrological studies in oil palm plantations are carried out at the plot scale, while oil palm plantations can reach thousands of hectares across several watersheds [121]. Indeed, research on the hydrologic impacts of oil palm plantations at the scale of watersheds is rare [153].

Quantitative data from field measurement on the relationship between water availability at each stage and water yield are still limited as well as the actual water use of oil palm at the field level, and the minimum amount of water needed to optimize oil palm productivity [156]. Research on the impact of oil palm cultivation on hydrology is still focused mainly on the study of plot-scale ecohydrological fluxes, such as the impact of tree age on canopy rainfall interception $[157,158]$ and transpiration rates in palms with varying ages and grown on different slopes $[152,159]$.

However, in general, large scale conversions of forests to intensively managed plantations, result in significant changes in the hydrological cycle including periodic water scarcity $[122,160]$. In natural ecosystems, such as forests, most of the rainfall water is absorbed by the soil and plays a role in increasing plant transpiration and replenishing groundwater. In oil palm monoculture plantations, water does not penetrate the eroded and compacted soil properly [122]. Decreased infiltration reduces water storage [124] and increases surface runoff [121] potentially reducing the access to usable water and increasing the risk of flooding [161].

It is well known that highly productive monoculture stands are dependent on an abundant supply of water over time [150]. Indeed, drainage on oil palm plantations can lead to a substantial reduction in streamflow during dry seasons or droughts, soil subsidence, and potentially increasing future flood risks [162]. Thus, the expansion of oil palm plantations will affect water consumption which, in the long term, could affect local water resources [118]. Rather than to high water use of oil palms per se, local water scarcity seems connected to the modified redistribution of water after precipitation at the landscape scale, reducing effective buffering [122].

There may be a potential trade-off between water use and management intensity of oil palm plantations [154]. Optimizing water use and oil palm production and increasing cultivated varieties can result in more efficient land use and reduced conversion of natural landscapes [153]. The practices of retaining old palms during crop rotation and cultivating ground cover crops can mitigate some of the impacts [118]

Retaining a riparian buffer zone helped reduce the negative impacts of oil palm plantations on streams [163,164]. A good riparian zone with dense native vegetation of complex structure adjacent to the streams that flow through the plantations can help restrict the transport of soil, sediment from the oil palm land, and in preventing chemicals pollutant from reaching waterways. They can also serve as valuable natural habitats for riparian and terrestrial species, as well as carbon storage areas. Appropriate riparian zone management, combined with effective monitoring, is essential to maintain or enhance the ecological function and biodiversity of stream ecosystems [165].

\subsection{Greenhouse Gas Emissions}

Forest conversion to oil palm is responsible for significant net greenhouse gas (GHG) emissions $[116,124,128,139,166]$. However, information of net carbon emissions throughout the life of the oil palm plantation, especially on peat soils, is still very limited [167]. Aboveground C stocks in oil palm plantation are, averaged over a plantation life-cycle, around $40 \mathrm{tC} \mathrm{ha}^{-1}$, which is lower than most predecessor vegetation (unless this is 'grassland'), leading to a 'carbon debt' in the first cycle $[168,169]$. On mineral soils, good-practice management can maintain soil carbon levels over a production cycle (compensating for early losses) [170]. Intensive use of fertilizer to increase yields adds greenhouse 
gas emissions as well, and the environmental optimum, minimizing the footprint per unit of palm oil, depends on context [171]. A synthesis of peat-oxidation emission values for tropical peatland by the Intergovernmental Panel on Climate Change [172], suggested default values of $51 \mathrm{Mg} \mathrm{CO}_{2} \mathrm{ha}^{-1} \mathrm{y}^{-1}$ for smallholder systems, $55 \mathrm{Mg} \mathrm{CO}_{2} \mathrm{ha}^{-1} \mathrm{y}^{-1}$ for commercial plantations (oil palm, industrial timber), and $10 \mathrm{MgCO}_{2} \mathrm{ha}^{-1} \mathrm{y}^{-1}$ for disturbed secondary forest. A recent study in smallholder oil palm on peat soils in Jambi suggested values may be higher [173] than that. While the 'moratorium' has restricted large-scale oil palm development on peat soils, smallholder expansion continues and becomes a more prominent part of the overall problem.

\section{Policy Responses and Options}

\subsection{FZ-OP as a Policy Issue}

From the evidence so far, we conclude that FZ-OP is a substantive issue that cannot be denied or ignored at the policy level. Credible spatial data sets indicate that $15-20 \%$ of Indonesian oil palms are growing within the forest zone, with FZ-OP identified in all provinces in which oil palm is grown. FZ-OP is, however, unevenly distributed in Indonesia, with the provinces of Riau and Central Kalimantan, where agreement between provincial and national authorities over the boundaries of the forest zone was only reached in 2014, as the main contributor. But even if these two provinces are seen as a 'policy anomaly', the case studies in the neighboring provinces of Jambi and West Kalimantan showed that FZ-OP is real, but of mixed history and characteristics that need to be understood before appropriate policies can be designed. FZ-OP is most common within the 'production forest' category, but also includes 'watershed protection forest' and 'conservation areas'. The probability that a unit of land in the elevation and climate zone suitable for oil palm has been converted to oil palm varies from more than $10 \%$ to around $1 \%$ in conservation areas (Figure A1). Taking palm oil production as a point of reference for the two case-study provinces, up to $14 \%$ may derive from $14 \%$ production forests and up to $3 \%$ from protection forests and conservation areas. As there is no legal basis for oil palm presence within the forest zone, any FZ-OP indicates a lack of legality. Whether it indicates a loss of forest functions or not depends on the comparator land cover-which in the case of production forest can be an industrial timber plantation, with properties similar to oil palm, but should be naturally established in the protection and conservation forests, with substantially higher diversity. Meanwhile, three types of oil palm owners (large-scale plantations, tied or vertically integrated smallholders, and independent smallholders) represent different social contexts and likely require differentiated policy responses. Such responses can focus on rights and permits in land use and water management, or on the transport and processing stages of the value chain.

\subsection{Institutional Responses}

Given the importance of palm oil exports for the Indonesian economy (around 7\% of total export value), the initial 'denial' phase of environmental issues around its production was promoted by the industry and its supporters in the Ministry of Economic Affairs. Yet, with 15-20\% of the production area (and a probably lower share of the harvested produce) potentially spoiling the national reputation of all palm oil, the phase of 'shooting the messengers' ended, and communication efforts shifted to demonstrating active responses, while emphasizing the social dimensions of smallholder interests in escaping from rural poverty [26].

\subsubsection{RSPO—Market Segmentation ('Shifting Blame')}

The Round Table for Sustainable Palm Oil (RSPO) is a private sector-led initiative set up in 2004 to counter environmental and social concerns surrounding the rapid expansion of oil palm. It is often regarded as the most credible sustainability scheme in the oil palm sector and has among the most stringent and explicit principles and criteria [174,175]. Still, more critical analyses emphasize that RSPO certification merely provides a technical managerial solution to satisfy mainly Northern 
sustainability concerns but does not touch upon the underlying social relations in the production of the commodity that needs to be improved for truly sustainable palm oil production [176]. Examples of this are land and labor rights issues in Indonesia, unequal distribution of profits, but also the fact that even RSPO-certified oil palm monocultures present a huge loss of biodiversity compared to the forests, whether primary, secondary, or agro-forestry systems [171]. Moreover, the RSPO is voluntary and in 2015 covered an estimated 15\% of Indonesia's oil palm area. With plenty of 'brown' supply chains to accommodate plantations that do not join RSPO, it is clear that this initiative cannot change the sector as a whole [88,177]. Santika et al. [178] also note that RSPO certification has not improved the wellbeing of local communities. They associate this with the considerably larger size of RSPO-certified plantation compared to non-certified plantations, which leaves little space for, especially forest-dependent, communities to maintain their livelihoods. Although the RSPO acknowledges that the inclusion of small and medium-sized growers is a key target [179], these small and medium actors are struggling with the costs, knowledge and institutional requirements needed for certification. With RSPO definitions of sustainability, there appears a clear risk that especially large corporate actors are classified as 'sustainable', as these are better able to fulfill RSPO criteria. Smaller actors on the other hand run the risk of being marginalized and blamed for the broader ills as land management and poor rural development strategies, for which oil palm is only one of many accelerants.

\subsubsection{ISPO—National Sovereignty}

Transnational business initiatives as the RSPO do not include governments. The Government of Indonesia, as well as the Indonesian Palm Oil Association (IPOA/GAPKI), regarded such initiatives as primarily reflecting Northern concerns, hollowing out the role of the State, and threatening the socio-economic development within Indonesia [180,181]. Therefore, in 2011, the Indonesian government launched the Indonesian Sustainable Palm Oil (ISPO) initiative to regain momentum and authority in sustainability discussions and to develop a sustainability framework that bypasses hard-to-comply-with sustainability criteria that are not demanded in key Southern markets such as China, India, and Indonesia itself [182]. However, ISPO requires compliance with existing legislation and whereas at first it is only mandatory for company palm oil plantations, with the latest update in 2020 it will obligatory for smallholders in five years, as well. The large area of smallholder SF-OP cannot be certified by ISPO under current rules and will prevent the target of full ISPO coverage to be achieved-unless the rules change and existing SF-OP can become legal. This will require the Ministry of Environment and Forestry and the Ministry of Agriculture to reach an agreement on how this can be done.

From the start, the ISPO organization suffered a lack of capacity to implement its mandate [183], and its principles and criteria are often deemed insufficient for guaranteeing sustainable development $[169,184]$. Although ISPO has been revised and supposedly strengthened in 2015 and 2020, the latest update of ISPO still poorly addresses human rights issues, lacks protection for non-primary forests, and lacks clear definitions, procedures and independent monitoring [185]. Again, as with RSPO, current smallholder certification only reaches a fraction of the total number of smallholders and smallholder exclusion looms.

\subsubsection{Deregulation and Crisis Responses}

Recently the Indonesian parliament adopted an 'omnibus' law that, to facilitate business development and job creation, removes legal obligations for environmental impact assessment, simplifies procedures for obtaining permits, and abolishes the requirement for plantations to support smallholder producers as part of their land concessions. The law has been critiqued as both environmental and social (worker rights) concerns appear to lose existing safeguards. Its consequences for the SF-OP issue are not yet clear. 


\subsection{Current Policy Options Based on Land and Water Management}

Several policy options have been discussed in the public debate so far, summarized in Table 5 . Just as 'stop the bleeding' is the first line of medical defense in dealing with injuries, the first efforts made, through a 'moratorium' are efforts to stop a further expansion of tree crops within the forest zone. Once some opportunity has been created for evaluating longer-term options, these can be linked to the diversity of contexts, in a 'policy options by context' table (Table 5), that requires an evaluation from the full range of relevant stakeholders before negotiations can progress and decisions with a chance of implementation success can be made. The options can target the land-base for oil palm production and/or the transport and entry into the mills and further value chains (compare Figure 7).

\subsubsection{Legalize by Including Oil Palm in Forest Definition}

The simplest solution to any illegality issue, at least from a formal governance perspective, is to legalize it. As the internationally used forest definition is ambiguous as to the 'tree' concept that underpins quantitative criteria about canopy cover and spatial scale, an argument can be made that palms, including Elaeis guineensis, are included in the woody perennial category, while quantitative criteria on potential tree height, the density of the canopy cover and longevity are easily within the range of what are commonly understood to be 'forestry trees'. Such an approach would avoid complexity, but not address any of the environmental and social concerns of the status quo. It would, however, put the pulp and paper industry, supported by Forestry authorities as core economic activity, and the oil palm industry on a level playing field. It will make all oil palm production deforestation-free by definition and greatly help in achieving the target that all of the Indonesian palm oil can be ISPO-certified, without major changes on the ground.

However, as simple and attractive as the option may seem in the short term, it would severely undermine Indonesia's international standing as a country balancing development and environmental concerns. It would also open the door for a much further expansion of oil palm within forests, without legal means to control such expansion.

\subsubsection{Grandfathering}

As part of an overall policy package, a grandfathering approach here refers to defining a cut-off date that tolerates (although not fully legalizes) oil palm cultivation in the forest zone if started before an agreed date. It is a common practice where 'new' regulations emerge, such as the RSPO standards that refer to the time standards were published. It would normally be restricted to the current plantation cycle and not allow replanting of oil palm.

A 'grandfather' approach could be a policy option that shares responsibility for the status quo and its path dependency where government agencies have been involved in the facilitation of illegal activities. Where smallholders from the local or indigenous communities shifted to oil palm from past rubber involvement in their swidden/fallow rotations they may have done so on land that is classified as 'production forest' but has not been formally gazetted. In the two provinces with the highest fraction of forest-zone oil palm, the designation of forest zone has remained contested between provincial and national forest authorities until 2014, creating a grey zone in which law enforcement was a low priority.

A case could also be made for migrants who moved to the frontier area for income generation, not for investment and capital accumulation (as 'white-collar' farmers). Part of these migrants (or their parents) were mobilized by the government through the "transmigration program" and looked for opportunities to increase their land, acquiring land from informal local land markets that disrespect forest zone categorization. Where this happened in the past, a 'generic pardon' or grandfather rule could close the books on it—but at risk of setting precedents that current rules can still be breached. 
Table 5. Policy options to deal with oil palm within the forest zone, by applicability domain.

\begin{tabular}{|c|c|c|c|c|c|c|c|}
\hline \multirow[t]{2}{*}{ Policy Option } & \multicolumn{4}{|c|}{ Applicability Domain } & \multicolumn{3}{|c|}{ Expected Consequences } \\
\hline & Conservation Areas & $\begin{array}{l}\text { Protection/Production } \\
\text { Forest on Peat }\end{array}$ & $\begin{array}{l}\text { Protection Forest } \\
\text { on Mineral Soil }\end{array}$ & $\begin{array}{c}\text { Production Forest } \\
\text { on Mineral Soil }\end{array}$ & Social & Economic & Environmental \\
\hline \multicolumn{8}{|l|}{ Land-focused: } \\
\hline 1.Legalize & NA & NA & NA & NA & ++ & ++ & - \\
\hline 2. Grandfathering & NA & NA & $\mathrm{A}$ & A & + & + & $+/-$ \\
\hline 3. Evict & NA & NA & NA & NA & - & - & $+/-$ \\
\hline 4. Charge & A & NA & A & A & $+/-$ & $+/-$ & $+/-$ \\
\hline 5. Agroforestry concessions & NA & A & A & A & + & $+/-$ & $+/-$ \\
\hline 6. Focus on high-value locations & A & $\mathrm{A}$ & A & A & $+/-$ & $+/-$ & + \\
\hline 7. Rewet peatlands & NA & A & NA & NA & $+/-$ & $+/-$ & + \\
\hline \multicolumn{8}{|l|}{ Value-chain based: } \\
\hline 8. Mill certification & A & NA & A & A & - & - & $+/-$ \\
\hline 9.Transport permits & A & NA & A & A & - & - & $+/-$ \\
\hline 10.Segment markets & A & NA & $\mathrm{A}$ & $\mathrm{A}$ & - & $+/-$ & $+/-$ \\
\hline
\end{tabular}

Remarks: A (applicable), NA (Not applicable) from a forestry institutional perspective. 


\subsubsection{Evict Farmers, Destroy the Crops}

On the other side of the spectrum from a blanket legalization of all forest-zone oil palm, there are voices for strict law enforcement. Evicting farmers and destroying their crops, to prevent their return, has been implemented before, e.g., in the 1990s in coffee encroachment areas in Sumatra. However, this sparked further conflicts, while the uprooting may have aggravated environmental issues in the short term, as did the type of reforestation with fast-growing exotic tree species in the longer term from an environmental perspective, as documented for Sumberjaya in Lampung (Sumatra) [185] and Manggarai (Flores) [186].

During the 'New Order' regime (1965-1998) military enforcement of government-set rules was common, but not free from corruption where economic interests were involved. After the regime change in 1998, reliance on court procedures, prisons and fines has shifted to the role of local governments in illegal procedures. However, attempts to sue provincial authorities in C Kalimantan and Riau for transgressing forest-zone rules backfired when the court found the forest zone in these provinces had not been gazette according to the prevailing Forestry Law [187].

In areas where production forests have been largely transformed into oil palm plantations for many years, such as in parts of Riau [91], it is unlikely that evicting small farmers, local upper-middle-class families, elites and companies with vested interests is feasible. They are not going to accept the destruction of their investment, and therefore this option may well be politically unachievable and risky. Already there have been cases where 'farmer groups' have held captive inspectors from the national authorities [188]. As highlighted elsewhere [111], the land mafia is making large profits with land conversion and in certain frontiers, this goes well beyond poor farmers looking for a few hectares of land [91]. Furthermore, the mere destruction of crops will not necessarily lead to increased environmental performance as oil palm plantations capture considerably more carbon than the degraded lands and Imperata (alang-alang) fields that destroyed plantations are likely to turn into. Heavily degraded lands without clear ownership and proper management are prone to fire and a key source of repeatedly occurring mass forest fires in Indonesia, with their detrimental effect on GHG emissions and human health [111,189].

\subsubsection{Charge Land-Owner Benefit Shares to Pay for Forest Management Elsewhere}

In Indonesia 'share-cropping' has a long tradition of arrangements where a land owner allows others to use farmland, based on a share of the crop yield obtained. Such arrangements are often preferred by both parties over hired labor or land rent contracts; the land owners share of the yield, the payment for and accounting of agricultural inputs tend to vary with local circumstances and the supply-demand balance for contracts. Often patron-client relations are involved with social dimensions beyond economic rationality. Rules can apply to trees, as well as to land as a production factor [190]. In the tradition of the Java Social Forestry program, forest authorities allowed farmers to grow annual crops, perennial fodder grass, or low-stature tree crops such as coffee under similar rules of a yield-share for the forest authorities [15]. Reference to such a system could lead to a financial charge on oil palm in the forest zone, for example within production forest lands where gazettement has been completed and the state is the legal owner.

Currently, forest management, from protected areas to production forests that are in the recovery phase, is severely restricted by lack of funding. Charging a land owner's share of palm oil produced within the production forest zone could provide funding for forest management elsewhere.

Of the 3.4 M ha oil-palm (OP) plantation in state forest areas, 700,000 ha is smallholder OP [75]. Rules may have to be differentiated by scale, for example, distinguishing between oil palm farm sizes of $>100,25-100,5-25$, and $0-5$ ha, as only the last category is likely to be a family farm without external labor. Such differentiation could be part of the Social Forestry (SF) and Agrarian Reform (AR)/UUCK schemes. A legal basis for such charges could be found in Law 32/2009 on Environment protection and management. 
If ways can be found to implement this, it will be attractive to local forest authorities-possibly too attractive and providing incentives for further oil palm expansion within the forest zone.

\subsubsection{Agroforestry Concession}

Peru, dealing with similar issues of past undocumented and illegal agricultural encroachment into forest zones, has created a legal category of an 'agroforestry concession' [191]. These schemes allow for agreements that re-establish government authority over forest lands but allow current tree-based land uses to continue, within agreed conditions. They resolve the issue that the current illegality of the land use is a bottleneck for government support of any type in the area, including a lack of extension services that restrain the development of socially and environmentally desirable practices. Similar issues have been noted in Riau, where support for companies and especially oil palm farmers in the forestry domain has been minimal to non-existent as illegal activities cannot formally be supported [91,92].

Agroforestry concessions as a legal instrument would complement current 'community-based forest management' and 'village forest' schemes, without claims that oil palm plantations are considered 'forests'. They would also allow investment in upgrading different types of production systems, systems that are more acceptable than mere oil palm monocultures. Current research interests in testing diversified oil palm agroforestry systems are opening new perspectives that might match farm economies [192-194].

\subsubsection{Swaps with High-Value Legal Deforestation Locations}

Side-by-side with the $3.6 \mathrm{M}$ of illegal oil palm in the forest zone, there is still a substantial area (1.2 M ha by recent estimates [195]) of old-growth forest that has been legally transferred (PKH/release) to large scale oil palm development (as a land bank), but has not yet been converted into oil-palm plantations. Earlier efforts under a 'land swap' umbrella to exchange land for companies with such concession rights have not had much impact [196], but in combination with a substantial landowners' charge on existing illegal forest-zone oil palm, it may be feasible to recover high-value forest while giving up (from a forestry perspective) production forest land already converted. The challenge is, however, that such swaps usually involve locations in different districts or even provinces. Other high-value locations that deserve priority in resolving existing forest-zone oil palm are riparian zones and ecological corridors.

Specific ideas have been formulated on how such swaps could, in the context of the Oil Palm moratorium, return existing non-converted OP concessions to government control. It could be implemented by buying out rightsholders using funds obtained by charging FZ-OP units of more than 25 ha based on Law 32/2009 on Environmental protection and management, charging land-rents to 'big smallholder $\mathrm{OP}^{\prime}$ ( $\left.5-25 \mathrm{ha}\right)$, while 'real smallholder OP' ( $<5 \mathrm{ha}$ ) could be exonerated in a Social Forestry (SF) and Agrarian Reform (AR)/UUCK perspective.

What has yet to be explored, however, is how the records on spatial boundaries of forest zone would be adjusted to 'legalize' the FZ-OP for the longer term. Moreover, it is unclear how such swaps would be understood internationally, and whether the smallholder OP can, after such swaps, enter international markets within a 'deforestation-free' label. One would have to explain that the oil palms were planted on illegally deforested land, but became legalized because elsewhere deforestation had been legalized, did not happen and its rights were withdrawn. This will be quite a mouthful of legalese, that only has a chance if the Government that implements such schemes has a record of transparency beyond what currently exists.

\subsubsection{Rewet Peatlands}

Specific solutions are needed for peatland forests converted to oil palm. The current situation of illegality makes it hard for government agencies to engage. For example, oil palm plantations located in Riau peatlands that were part of the Forestry Domain suffered severe water table management issues, with larger farmers just digging canals without coordination, leading to drought and flooding, 
leaving the area prone to peat fires [91]. Such undesirable practices, which are relevant in other landscapes as well [92], may be countered by (partial, temporary or full) legalization of their plantations, charging farmers for their activities in the forestry domain and using these proceeds to finance and coordinate proper water table management. Such an approach may lead to landscape-wide improved water table management and associated reductions in draught, fire, flooding and associated GHG emissions. The government rules about maintaining groundwater tables in peatlands no deeper than $40 \mathrm{~cm}$ below the surface are not incompatible with growing oil palm —at least not under smallholder, non-mechanized management.

\subsection{Policy Options Based on Transport and Processing}

\subsubsection{Impose Legality Checks at the Mills}

Current sustainability initiatives as RSPO and ISPO heavily depend on legality checks at the mill, restricting certification to mills with adequate traceability of the fresh fruit bunches they obtain. However, supply chain characteristic for especially independent smallholders, who usually sell to middlemen that mix and may resell their produce to other traders, are unable to fully trace all produce that enters the mills. This system appears to benefit especially the larger actors, who have the most integrated value chains, shifting blame and costs to others. As noted elsewhere $[29,30]$ certification may solve problems of guilt for downstream users who do not want to be part of value chains with negative social and environmental consequences, but it may primarily shift blame, rather than transforming other means of production, unless economic signals, accounting for increased transaction costs, are sending a clear message.

\subsubsection{Apply a Transport Permit System}

Forestry has a long history of trying to control illegal logging by applying transport systems and road checks. As documented for charcoal trade in Africa [197], it can increase transaction costs by legal and illegal levies, with little impact other than reducing farmgate profitability at the sites of production. This approach thus suffers similar drawbacks as legality checks at the mills. It is prone to corruption. In areas where there are a lot of roads, this becomes cumbersome. However, in some contexts where there is less infrastructure, it may work to some extent.

\subsubsection{Segment Markets}

Legality checks at the mills and chain of custody rules [93], potentially supported by transport permit systems, can support the bifurcations into 'green' and 'brown' supply chains, targeting different market segments (e.g., international and domestic). It will not solve the issue of illegal forest-zone oil palm, but it may affect the profitability of the lower-grade production system if transaction costs of the certification are controlled or subsidized. The new EU anti-deforestation policy and RSPO are heading in this direction, recognizing that importing countries have to respect the sovereignty of producing countries within world trade rules. Keep your own street clean and shift blame for existing problems to others. The EU with its deforestation-free supply chains is picking the low-hanging fruits, with a 'grandfather' cut-off date for deforestation before 2008, which can easily cover EU demands, whilst leaving the tougher issues to other parties.

\subsection{Follow-Up Policy Research}

Table 5 provides an early assessment of ten policy options for four subcategories of FZ-OP, from three overarching perspectives. The tentative evaluation of options could be the start of a further process of stakeholder consultations, that may modify perspectives on expected effectiveness and acceptability by main stakeholder groups. As some of the options proposed, especially the 'agroforestry concession' idea would be new to the Indonesian forest management framework, deeper analysis of legal opportunities and consequences will be needed before specific recommendations can be made. 


\section{Conclusions}

Up to one-fifth of oil palms in Indonesia are located within the 'forest zone' (Kawasan hutan), especially in lands indicated as production forest, with smaller fractions in protection forest and conservation areas and substantial variation between the provinces and islands. Two (out of 34) provinces are responsible for two-thirds of the forest-zone oil palm, while harboring nearly one-third of Indonesian oil palms. While state-owned and private large-scale plantations dominated in the early expansion phase of oil palm, smallholders have become prominent, especially in Sumatra, where $60 \%$ of oil palm capacity is located, especially those without a contract with mills ('independents'). Part of the smallholder oil palm within the forest zone has been derived from earlier agroforests (often rubber-based).

As there is no legal basis for oil palm within the forest zone, one-fifth of Indonesia's oil palms cannot meet current criteria for sustainability certification, whether the voluntary international RSPO standard or the domestic ISPO standard. Solutions for the ensuing policy problem will have to differentiate between the primary forest functions indicated for different parts of the forest zone, with the smallest gap between desired function and current reality in the production forest zone, where most of the oil palms are located, and largest gap for the small fraction $(<1 \%)$ of oil palms in conservation areas. Policies will have to differentiate between the scale of the production unit, the opportunities to charge a 'land owner's' share by forest authorities, the history of the conversion process, and the expected impact through discouraging further expansion.

Policy options for dealing with forest-zone oil palm can focus on the land where oil palms are grown and/or on the transport and mills that are processing the fresh fruit bunches produced. Where mill-based regulation can be effective in segregating the market and ensuring that part of the supply chain is 'deforestation-free', it is unlikely to close marketing channels for forest-zone oil palm products. Land-based options will have to explore a middle ground as neither blanket legalization of oil palm as a forest commodity, nor evictions and destroying of the crops are realistic in the institutional context. Combinations of financial charges and permits for agroforestry development may be the most feasible basis of a negotiated policy package. Further policy research and stakeholder consultations will be needed before specific policy recommendations can be made, adjusted to the legal environment and responsibilities of national, provincial and district-level government authorities, as well as likely responses of international trade and domestic industry.

Author Contributions: Conceptualization, E.P., H.S., I.J., A.W. and M.v.N.; Investigation, E.P., H.S., I.J., A.W., H.Y.S.H.N. and M.v.N.; Methodology, E.P., A.W. and M.v.N.; Writing—original draft, E.P., H.S., I.J., A.W., H.Y.S.H.N. and M.v.N.; Writing-review \& editing, E.P., H.S., I.J., A.W. and M.v.N. All authors have read and agreed to the published version of the manuscript.

Funding: This research is financially supported by the Forested Landscape for Equity (GLA 1.0) project, Component: Sustainable Agrocommodity Landscape (No. Project 04400407) managed by Tropenbos Indonesia.

Acknowledgments: The authors acknowledge the availability of spatial data sets through Yves Laumonier (CIFOR), Lilik Prasetyo and Aryo Condro. The National Main Commodity Maps in Indonesia (Condro et al. (2020)) were produced under collaboration between the Faculty of Forestry, IPB, and the United Nations Development Programme (UNDP). We acknowledge questions and inputs from speakers and participants of the on-line seminar on 26 September 2020.

Conflicts of Interest: The authors declare no conflict of interest.

\section{Appendix A}

\section{Appendix A.1. Details of the Initial Stakeholder Consultation}

The webinar "The Future of Agro-Commodities in Forest Areas" on 26 September 2020 had 373 registered participants. They attended the on-line event geographically spread over 33 (out of 34) provinces; institutionally, $30 \%$ represented government agencies (local, national; forestry, non-forestry), 
$3 \%$ research organizations, $44 \%$ universities, $11 \%$ private sector, $13 \%$ NGO's. Demographically $35 \%$ was female and $27 \%$ below 25 years of age.

As first speaker the Director General of Natural Resources and Ecosystem Conservation (KSDAE), Ministry of Environment and Forestry (KLHK), Ir. Wiratno, MSc, marked the shift from a timber focus in the past to a much wider range of economic commodities as potentially derived from and grown in forests, as long as the societal functions of forests can be secured. Speakers from NGO's reviewed data on forest-associated poverty levels (around $21 \%$ of poor people in Indonesia are forest villagers) and presence of tree crops, with most specific debate about oil palm.

The discussion focused on the reliability of data of various sources and on opportunities to resolve issues through implementation of Law No.34/2014 on Soil and Water Conservation and Government Regulation No.46/2017 on Environmental Economic Instruments. Panelists emphasized a need for the involvement of government agencies in intensive assistance for large-scale plantations and smallholders in forest areas, and for law enforcement for deliberate occupation in forest areas and resolving tenure issues. The various strands of discussion informed the current manuscript.

\section{Appendix A.2. Analysis of FZ-OP by Elevation Zone and Forest Class}

The spatial data on FZ-OP and oil palm on non-forest lands are differentiated by forest class and elevation in Figure A1.
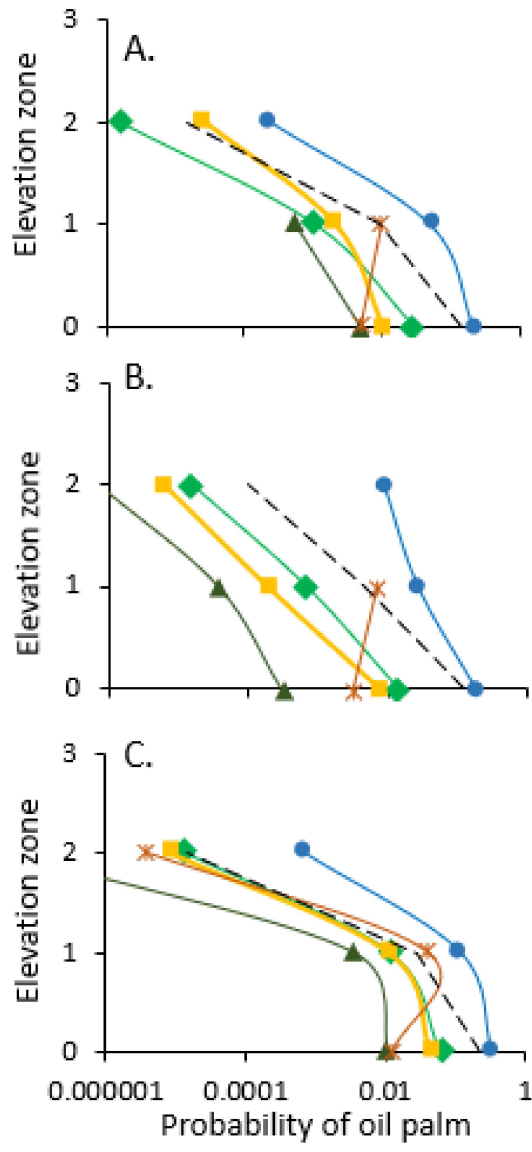
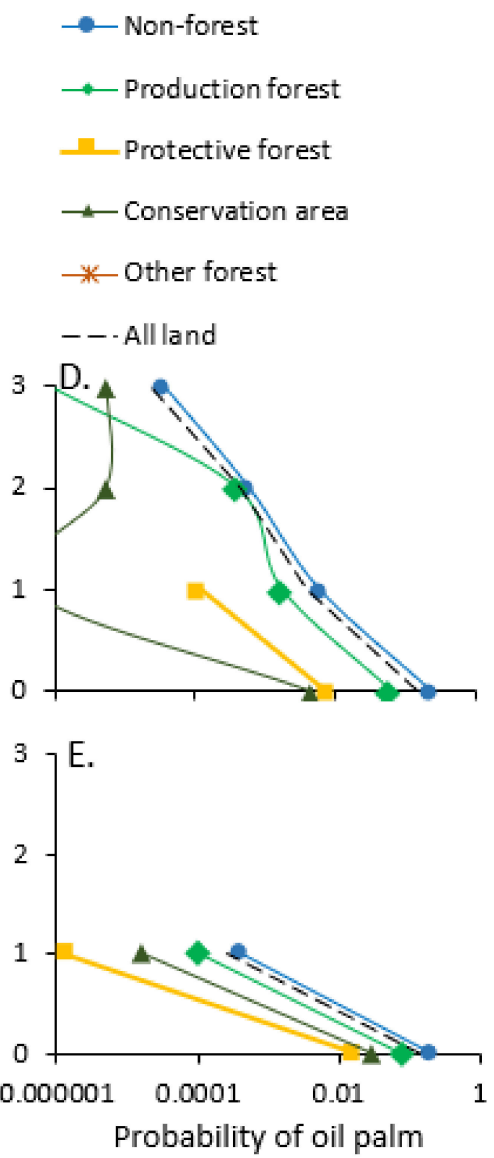

Figure A1. Probability of land having oil palm as land cover at four elevation zones $(0=0-100$; $1=100-300 ; 2=300-1000 ; 3=>1000 \mathrm{~m}$ a.s.l.) in two provinces ((A-C), West Kalimantan; (D,E) Jambi), for specified land use designations outside and inside the forest-zone, according to three data sources ((A) [75]; (B,D) [33]; (C,E) [28]); (NB log scale on the X-axis). 


\section{References}

1. Chazdon, R.L.; Brancalion, P.H.; Laestadius, L.; Bennett-Curry, A.; Buckingham, K.; Kumar, C.; Moll-Rocek, J.; Vieira, I.C.G.; Wilson, S.J. When is a forest a forest? Forest concepts and definitions in the era of forest and landscape restoration. Ambio 2016, 45, 538-550. [CrossRef]

2. van Noordwijk, M.; Minang, P.A. If We Cannot Define It, We Cannot Save It; ASB Policy Brief 15; ASB Partnership for the Tropical Forest Margins: Nairobi, Kenya, 2009; p. 4. Available online: http://www.asb.cgiar.org/ pdfwebdocs/ASBPB15.pdf (accessed on 24 October 2020).

3. de Foresta, H.; Temu, A.; Boulanger, D.; Feuilly, H.; Gauthier, M. Towards the Assessment of Trees Outside Forests: A Thematic Report Prepared in the Framework of the Global Forest Resources Assessment 2010; Food and Agriculture Organization of the United Nations: Rome, Italy, 2013.

4. van Noordwijk, M.; Suyamto, D.A.; Lusiana, B.; Ekadinata, A.; Hairiah, K. Facilitating agroforestation of landscapes for sustainable benefits: Tradeoffs between carbon stocks and local development benefits in Indonesia according to the FALLOW model. Agric. Ecosyst. Environ. 2008, 126, 98-112. [CrossRef]

5. Romijn, E.; Ainembabazi, J.H.; Wijaya, A.; Herold, M.; Angelsen, A.; Verchot, L.; Murdiyarso, D. Exploring different forest definitions and their impact on developing REDD+ reference emission levels: A case study for Indonesia. Environ. Sci. Policy 2013, 33, 246-259. [CrossRef]

6. FAO. Global Forest Resources Assessment 2010; FAO Forestry Paper No. 163; UN Food and Agriculture Organization: Rome, Italy, 2010.

7. Keenan, R.J.; Reams, G.A.; Achard, F.; de Freitas, J.V.; Grainger, A.; Lindquist, E. Dynamics of global forest area: Results from the FAO Global Forest Resources Assessment 2015. For. Ecol. Manag. 2015, 352, 9-20. [CrossRef]

8. van Dijk, K.; Savenije, H. Oil Palm or Forests? More Than a Question of Definition; Policy Brief; Tropenbos International: Wageningen, The Netherlands, 2010.

9. van Noordwijk, M.; Dewi, S.; Minang, P.; Simons, T. 1.2 Deforestation-free claims: Scams or substance. In Zero Deforestation: A Commitment to Change; No. 58; Tropenbos International: Wageningen, The Netherlands, 2017; pp. 11-16.

10. Sasaki, N.; Putz, F.E. Critical need for new definitions of "forest" and "forest degradation" in global climate change agreements. Conserv. Lett. 2009, 2, 226-232. [CrossRef]

11. Zomer, R.J.; Trabucco, A.; Verchot, L.V.; Muys, B. Land area eligible for afforestation and reforestation within the Clean Development Mechanism: A global analysis of the impact of forest definition. Mitig. Adapt. Strateg. Glob. Chang. 2008, 13, 219-239. [CrossRef]

12. Fay, C.; Michon, G. Redressing forestry hegemony when a forestry regulatory framework is best replaced by an agrarian one. For. Trees Livelihoods 2005, 15, 193-209. [CrossRef]

13. Silvianingsih, Y.A.; Hairiah, K.; Suprayogo, D.; van Noordwijk, M. Agroforests, swiddening and livelihoods between restored peat domes and river: Effects of the 2015 fire ban in Central Kalimantan (Indonesia). Int. For. Rev. 2020, 22, 382-396. [CrossRef]

14. Akiefnawati, R.; Villamor, G.B.; Zulfikar, F.; Budisetiawan, I.; Mulyoutami, E.; Ayat, A.; van Noordwijk, M. Stewardship agreement to reduce emissions from deforestation and degradation (REDD): Case study from Lubuk Beringin's Hutan Desa, Jambi Province, Sumatra, Indonesia. Int. For. Rev. 2010, 12, 349-360. [CrossRef]

15. Cahyono, E.D.; Fairuzzana, S.; Willianto, D.; Pradesti, E.; McNamara, N.P.; Rowe, R.L.; van Noordwijk, M. Agroforestry Innovation through Planned Farmer Behavior: Trimming in Pine-Coffee Systems. Land 2020, 9, 363. [CrossRef]

16. Van Noordwijk, M.; Zomer, R.J.; Xu, J.; Bayala, J.; Dewi, S.; Miccolis, A.; Cornelius, J.P.; Robiglio, V.; Nayak, D.; Rizvi, J. Agroforestry options, issues and progress in pantropical contexts. In Sustainable Development through Trees on Farms: Agroforestry in Its Fifth Decade; Van Noordwijk, M., Ed.; World Agroforestry (ICRAF): Bogor, Indonesia, 2019.

17. Van Noordwijk, M.; Williams, S.; Verbist, B. Towards integrated natural resource management in forest margins of the humid tropics: Local action and global concerns. In ASB Lecture Notes; ICRAF: Bogor, Indonesia, 2001.

18. Hansen, M.C.; Potapov, P.V.; Moore, R.; Hancher, M.; Turubanova, S.A.; Tyukavina, A.; Thau, D.; Stehman, S.V.; Goetz, S.J.; Loveland, T.R.; et al. High-resolution global maps of 21st-century forest cover change. Science 2013, 342, 850-853. [CrossRef] [PubMed] 
19. Zomer, R.J.; Neufeldt, H.; Xu, J.C.; Ahrends, A.; Bossio, D.; Trabucco, A.; van Noordwijk, M.; Wang, M. Global tree cover and biomass carbon on agricultural land: The contribution of agroforestry to global and national carbon budgets. Sci. Rep. 2016, 6, 29987. [CrossRef] [PubMed]

20. Thomas, S.; Dargusch, P.; Harrison, S.; Herbohn, J. Why are there so few afforestation and reforestation Clean Development Mechanism projects? Land Use Policy 2010, 27, 880-887. [CrossRef]

21. Corbera, E.; Schroeder, H. Governing and implementing REDD+. Environ. Sci. Policy 2011, 14, 89-99. [CrossRef]

22. Minang, P.A.; Van Noordwijk, M.; Duguma, L.A.; Alemagi, D.; Do, T.H.; Bernard, F.; Agung, P.; Robiglio, V.; Catacutan, D.; Suyanto, S.; et al. REDD+ Readiness progress across countries: Time for reconsideration. Clim. Policy 2014, 14, 685-708. [CrossRef]

23. Garrett, R.D.; Levy, S.; Carlson, K.M.; Gardner, T.A.; Godar, J.; Clapp, J.; Dauvergne, P.; Heilmayr, R.; de Waroux, Y.L.P.; Ayre, B.; et al. Criteria for effective zero-deforestation commitments. Glob. Environ. Chang. 2019, 54, 135-147. [CrossRef]

24. Sheil, D.; Casson, A.; Meijaard, E.; Van Noordwijk, M.; Gaskell, J.; Sunderland-Groves, J.; Wertz, K.; Kanninen, M. The Impacts and Opportunities of Oil Palm in Southeast Asia: What do We Know and What Do We Need to Know; Center for International Forestry Research: Bogor, Indonesia, 2009. [CrossRef]

25. Sayer, J.; Ghazoul, J.; Nelson, P.; Boedhihartono, A.K. Oil palm expansion transforms tropical landscapes and livelihoods. Glob. Food Secur. 2012, 1, 114-119. [CrossRef]

26. van Noordwijk, M.; Pacheco, P.; Slingerland, M.; Dewi, S.; Khasanah, N. Palm Oil Expansion in Tropical Forest Margins or Sustainability of Production? Focal Issues of Regulations and Private Standards; World Agroforestry (ICRAF): Bogor, Indonesia, 2017. [CrossRef]

27. Heilmayr, R.; Carlson, K.M.; Benedict, J.J. Deforestation spillovers from oil palm sustainability certification. Environ. Res. Lett. 2020, 15, 075002. [CrossRef]

28. Condro, A.A.; Setiawan, Y.; Prasetyo, L.B.; Pramulya, R.; Siahaan, L. Retrieving the National Main Commodity Maps in Indonesia Based on High-Resolution Remotely Sensed Data Using Cloud Computing Platform. Land 2020, 9, 377. [CrossRef]

29. Mithöfer, D.; van Noordwijk, M.; Leimona, B.; Cerutti, P.O. Certify and shift blame, or resolve issues? Environmentally and socially responsible global trade and production of timber and tree crops. Int. J. Biodivers. Sci. Ecosyst. Serv. Manag. 2017, 13, 72-85.

30. Leimona, B.; van Noordwijk, M.; Mithöfer, D.; Cerutti, P.O. Certifying Environmental Social Responsibility. Environmentally and socially responsible global production and trade of timber and tree crop commodities: Certification as a transient issue-attention cycle response to ecological and social issues. Int. J. Biodivers. Sci. Ecosyst. Serv. Manag. 2018, 13, 497-502. [CrossRef]

31. KLHK. Peta Penutupan Lahan Indonesia, 2000, 2010, 2018; Kementrian Lingkunan Hidup dan Kehutanan: Jakarta, Indonesia, 2018; Available online: http://geoportal.menlhk.go.id/arcgis/rest/services/ (accessed on 9 October 2020).

32. Pribadi, U.A.; Setiabudi Suryadi, I.; Laumonier, Y. West Kalimantan Ecological Vegetation Map 1:50000. 2020. Available online: https://data.cifor.org/dataset.xhtml?persistentId=doi:10.17528/CIFOR/DATA.00203 (accessed on 15 October 2020). [CrossRef]

33. Descals, A.; Wich, S.; Meijaard, E.; Gaveau, D.L.A.; Peedell, S.; Szantoi, Z. High-resolution global map of smallholder and industrial closed-canopy oil palm plantations. Earth Syst. Sci. Data Discuss 2020. [CrossRef]

34. SK Menteri Kehutanan no 733/2014. Available online: https:/fdokumen.com/document/sk-no733-tahun2014-penunjukan-kalbar.html (accessed on 30 October 2020).

35. SK Menteri Kehutanan no 863/2014. Available online: https://fdokumen.com/document/surat-keputusanmenteri-kehutanan-nomor-sk-863menhut-ii2014-tentang-kawasan.html (accessed on 30 October 2020).

36. Galudra, G.; Sirait, M. A discourse on Dutch colonial forest policy and science in Indonesia at the beginning of the 20th century. Int. For. Rev. 2009, 11, 524-533. [CrossRef]

37. Rachman, N.F.; Siscawati, M. Forestry Law, Masyarakat Adat and Struggles for Inclusive Citizenship in Indonesia. Routledge Handb. Asian Law 2016, 224-249. [CrossRef]

38. Bakker, L.; Moniaga, S. The space between: Land claims and the law in Indonesia. Asian J. Soc. Sci. 2010, 38, 187-203. [CrossRef]

39. Hermosilla, A.C.; Fay, C. Strengthening Forest Management in Indonesia through Land Tenure Reform: Issues and Framework for Action; The World Bank: Washington, DC, USA, 2005; p. 55. 
40. Ministry of Environment and Forestry. The State of Indonesia's Forest; Ministry of Environment and Forestry, Republic of Indonesia: Jakarta, Indonesia, 2018.

41. Suwarno, A.; van Noordwijk, M.; Weikard, H.P.; Suyamto, D. Indonesia's forest conversion moratorium assessed with an agent-based model of Land-Use Change and Ecosystem Services (LUCES). Mitig. Adapt. Strateg. Glob. Chang. 2018, 23, 211-229. [CrossRef] [PubMed]

42. Directorate of Peat Degradation Control. Penetapan Fungsi Ekosistem Gambut (Peatland Ecosystem Function Establishment). 2020. Available online: http://pkgppkl.menlhk.go.id/v0/penetapan-fungsi-ekosistemgambut/ (accessed on 15 October 2020).

43. Decree of Minister of Forestry No. 47/Kpts-II/1998 Concerning the Designation of +/- 29,000 Hectares of the Protective Forest and Limited Production Forest Zone, From the Pesisir Forest Grouping, in West Lampung District, Province of Lampung, Which Are Covered by Damar Agroforests ('Repong Damar') Managed by Communities under Customary Law (Masyarakat Hukum Adat), as a Zone with Distinct Purpose (Kawasan Dengan Tujuan Istimewa). Available online: https://peraturan.huma.or.id/pub/surat-keputusan-menterikehutanan-nomor-47-kpts-ii-1998 (accessed on 30 November 2020).

44. Kusters, K.; De Foresta, H.; Ekadinata, A.; van Noordwijk, M. Towards solutions for state vs. local community conflicts over forestland: The impact of formal recognition of user rights in Krui, Sumatra, Indonesia. Hum. Ecol. 2007, 35, 427-438. [CrossRef]

45. Michon, G. Domesticating Forests—How Farmers Manage Forest Resources; CIFOR: Bogor, Indonesia, 2005.

46. De Royer, S.; Van Noordwijk, M.; Roshetko, J.M. Does community-based forest management in Indonesia devolve social justice or social costs? Int. For. Rev. 2018, 20, 167-180. [CrossRef]

47. Rakatama, A.; Pandit, R. Reviewing social forestry schemes in Indonesia: Opportunities and challenges. For. Policy Econ. 2020, 111, 102052. [CrossRef]

48. Kelly, A.B.; Peluso, N.L. Frontiers of commodification: State lands and their formalization. Soc. Nat. Resour. 2015, 28, 473-495. [CrossRef]

49. Brown, D.W. Addicted to Rent: Corporate and Spatial Distribution of Forest Resources in Indonesia: Implications for Forest Sustainability and Government Policy; Indonesia-UK Tropical Forest Management Programme, Provincial Forest Management Programme: Jakarta, Indonesia, 1999.

50. Resosudarmo, B.P. (Ed.) The Politics and Economics of Indonesia's Natural Resources; Institute of Southeast Asian Studies: Singapore, 2005. [CrossRef]

51. Brown, T.; Leitmann, J.; Boccucci, M.; Jurgens, E. Sustaining Economic Growth, Rural Livelihoods, and Environmental Benefits: Strategic Options for Forest Assistance in Indonesia; Worldbank: Jakarta, Indonesia, 2006; Available online: http://documents1.worldbank.org/curated/en/986501468049447840/pdf/ 392450REVISEDOIDWBForestOptions.pdf (accessed on 24 October 2020).

52. Mulyani, M.; Jepson, P. REDD+ and forest governance in Indonesia: A multistakeholder study of perceived challenges and opportunities. J. Environ. Dev. 2013, 22, 261-283. [CrossRef]

53. Van Noordwijk, M.; Agus, F.; Dewi, S.; Purnomo, H. Reducing emissions from land use in Indonesia: Motivation, policy instruments and expected funding streams. Mitig. Adapt. Strateg. Glob. Chang. 2014, 19, 677-692. [CrossRef]

54. Singer, B.; Giessen, L. Towards a donut regime? Domestic actors, climatization, and the hollowing-out of the international forests regime in the Anthropocene. For. Policy Econ. 2017, 79, 69-79. [CrossRef]

55. Hall, D. Land grabs, land control, and Southeast Asian crop booms. J. Peasant Stud. 2011, 38, 837-857. [CrossRef]

56. Gouyon, A.; De Foresta, H.; Levang, P. Does 'jungle rubber' deserve its name? An analysis of rubber agroforestry systems in southeast Sumatra. Agrofor. Syst. 1993, 22, 181-206. [CrossRef]

57. Verbist, B.; Putra, A.E.D.; Budidarsono, S. Factors driving land use change: Effects on watershed functions in a coffee agroforestry system in Lampung, Sumatra. Agric. Syst. 2005, 85, 254-270. [CrossRef]

58. Ruf, F.; Ehret, P. Smallholder cocoa in Indonesia: Why a cocoa boom in Sulawesi? In Cocoa Pioneer Fronts Since 1800; Palgrave Macmillan: London, UK, 1996; pp. 212-231. [CrossRef]

59. Li, T.M. Practices of Assemblage and Community Forest Management. Econ. Soc. 2007, 36, 264-294. [CrossRef]

60. Galudra, G.; van Noordwijk, M.; Agung, P.; Suyanto, S.; Pradhan, U. Migrants, land markets and carbon emissions in Jambi, Indonesia: Land tenure change and the prospect of emission reduction. Mitig. Adapt. Strateg. Glob. Chang. 2014, 19, 715-731. [CrossRef] 
61. Pelzer, K.J. Pioneer Settlement in the Asiatic Tropics, Studies in land utilisation and agricultural colonization in southeastern Asia. In Pioneer Settlement in the Asiatic Tropics. Special Publication No. 29; American Geographical Society: New York, NY, USA, 1945.

62. De Koninck, R.; McTaggart, W.D. Land settlement processes in Southeast Asia: Historical foundations, discontinuities, and problems. Asian Res. Serv. 1987, 15, 341-356.

63. Angelsen, A. Forest Cover Change in Space and Time: Combining the von Thunen and Forest Transition Theories; The World Bank: Washington, DC, USA, 2007.

64. De Koninck, R. The challenges of the agrarian transition in Southeast Asia. Labour Cap. Soc. 2004, 37, $285-288$.

65. Dove, M. The Banana Tree at the Gate: A History of Marginal Peoples and Global Markets in Borneo; Yale University Press: New Haven, CT, USA, 2011.

66. Geertz, C. Agricultural Involution: The Processes of Ecological Change in Indonesia; Univ. of California Press: Berkeley, CA, USA, 1963.

67. van Noordwijk, M.; Bizard, V.; Wangpakapattanawong, P.; Tata, H.L.; Villamor, G.B.; Leimona, B. Tree cover transitions and food security in Southeast Asia. Glob. Food Secur. 2014, 3, 200-208. [CrossRef]

68. Potter, L. How can the people's sovereignty be achieved in the oil palm sector? Is the plantation model shifting in favour of smallholders. In Land and Development in Indonesia: Searching for the People's Sovereignty; McCarthy, J.F., Robinson, K., Eds.; ISEAS-Yusof Ishak Institute: Singapore, 2016; pp. 315-342.

69. Colfer, C.J.P.; Resosudarmo, I.A.P. Which way forward. In People, Forests and Policymaking in Indonesia; Resources for the Future: Washington, DC, USA, 2002.

70. Berkes, F.; Colding, J.; Folke, C. Rediscovery of traditional ecological knowledge as adaptive management. Ecol. Appl. 2000, 10, 1251-1262. [CrossRef]

71. Gadgil, M.; Olsson, P.; Berkes, F.; Folke, C. Exploring the role of local ecological knowledge in ecosystem management: Three case studies. In Navigating Social-Ecological Systems: Building Resilience for Complexity and Change; Berkes, F., Colding, J., Folkes, C., Eds.; Cambridge University Press: Cambridge, UK, 2003. [CrossRef]

72. Villamor, G.B.; Pontius, R.G.; van Noordwijk, M. Agroforest's growing role in reducing carbon losses from Jambi (Sumatra), Indonesia. Reg. Environ. Chang. 2014, 14, 825-834. [CrossRef]

73. Santika, T.; Wilson, K.A.; Budiharta, S.; Kusworo, A.; Meijaard, E.; Law, E.A.; Friedman, R.; Hutabarat, J.A.; Indrawan, T.P.; St John, F.A.; et al. Heterogeneous impacts of community forestry on forest conservation and poverty alleviation: Evidence from Indonesia. People Nat. 2019, 1, 204-219. [CrossRef]

74. Directorate General of Estate Crops. Tree Crop Estate Statistics of Indonesia 2018-2020-Palm Oil; Directorate General of Estate, Ministry of Agriculture: Jakarta, Indonesia, 2019.

75. Bakhtiar, I.; Suradiredja, D.; Santoso, H.; Saputra, W. Hutan Kita Bersawit-Gagasan Penyelesaian untuk Perkebunan Kelpa Sawit dalam Kawasan Hutan; KEHATI: Jakarta, Indonesia, 2019.

76. Gaveau, D.; Sheil, D.; Husnayaen Salim, M.A.; Arjakusuma, S.; Ancrenaz, M.; Pacheco, P.; Meijaard, E. Rapid conversions and avoided deforestation: Examining four decades of industrial plantation expansion in Borneo. Sci. Rep. 2016, 6, 3201. [CrossRef]

77. Meijaard, E.; Garcia-Ulloa, J.; Sheil, D.; Wich, S.A.; Carlson, K.M.; Juffe-Bignoli, D.; Brooks, T.M. (Eds.) Oil Palm and Biodiversity. A Situation Analysis by the IUCN Oil Palm Task Force; IUCN Oil Palm Task Force: Gland, Switzerland, 2018; p. 116. [CrossRef]

78. Austin, K.G.; Mosnier, A.; Pirker, J.; McCallum, I.; Fritz, S.; Kasibhatla, P.S. Shifting patterns of oil palm driven deforestation in Indonesia and implications for zero-deforestation commitments. Land Use Policy 2017, 69, 41-48. [CrossRef]

79. DJP. Statistik Perkebunan Indonesia; Kelapa Sawit 2018-2020; Direktorat Jenderal Perkebunan: Jakarta, Indonesia, 2020; p. 68.

80. Badan Pusat Statistik, Sistem Informasi Administrasi Kependudukan, Kemendagri, 2019. Indonesia Administrative Level 0-4 Boundaries, Indonesia (IDN) Administrative Boundary Common Operational Database (COD-AB), Update 23 December 2019, Badan Pusat Statistik, Sistem Informasi Administrasi Kependudukan. Kemendagri (Ministry of Home Affairs). Available online: https://data.humdata.org/dataset/indonesia-administrative-level-04-boundariesx (accessed on 16 May 2020).

81. Potter, L. Where Are the Swidden Fallows Now? An Overview of Oil Palm and Dayak Agriculture across Kalimantan, with Case Studies from Sanggau, in West Kalimantan. In Shifting Cultivation and Environmental Change: Indigenous People, Agriculture and Forest Conservation; Routledge: Abingdon, UK, 2015. 
82. Penot, E.; Chambon, B.; Wibawa, G. History of rubber agroforestry systems development in Indonesia and Thailand as alternatives for sustainable agriculture and income stability. Int. Proc. IRC 2017, 1, 497-532. [CrossRef]

83. Feintrenie, L.; Levang, P. Sumatra's rubber agroforests: Advent, rise and fall of a sustainable cropping system. Small-Scale For. 2009, 8, 323-335. [CrossRef]

84. Therville, C.; Feintrenie, L.; Levang, P. Farmers' perspectives about agroforests conversion to plantations in Sumatra. Lessons learnt from Bungo District (Jambi, Indonesia). For. Trees Livelihoods 2011, 20, 15-33. [CrossRef]

85. Koh, L.P.; Miettinen, J.; Liew, S.C.; Ghazoul, J. Remotely sensed evidence of tropical peatland conversion to oil palm. Proc. Natl. Acad. Sci. USA 2011, 108, 5127-5132. [CrossRef]

86. Afriyanti, D.; Hein, L.; Kroeze, C.; Zuhdi, M.; Saad, A. Scenarios for withdrawal of oil palm plantations from peatlands in Jambi Province, Sumatra, Indonesia. Reg. Environ. Chang. 2019, 19, 1201-1215. [CrossRef]

87. Global Forest Watch. Universal Mill List. 2020. Available online: http://data.globalforestwatch.org/datasets/ universal-mill-list/data (accessed on 21 March 2020).

88. ten Kate, A.; Kuepper, B.; Piotrowski, M. NDPE Policies Cover 83\% of Palm Oil Refineries; Implementation at 78\%. Available online: https://chainreactionresearch.com/report/ndpe-policies-cover-83-of-palm-oilrefineries-implementation-at-75/ (accessed on 25 October 2020).

89. Budidarsono, S.; Susanti, A.; Zoomers, A. Oil palm plantations in Indonesia: The implications for migration, settlement/resettlement and local economic development. In Biofuels—Economy, Environment and Sustainability; INTECH: London, UK, 2013; pp. 173-193. [CrossRef]

90. DJP. Statistik Perkebunan Indonesia; Kelapa Sawit; Direktorat Jenderal Perkebunan: Jakarta, Indonesia, 1990.

91. Jelsma, I.; Schoneveld, G.C.; Zoomers, A.; van Westen, A.C.M. Unpacking Indonesia's independent oil palm smallholders: An actor-disaggregated approach to identifying environmental and social performance challenges. Land Use Policy 2017, 69, 281-297. [CrossRef]

92. Schoneveld, G.C.; van der Haar, S.; Ekowati, D.; Andrianto, A.; Komarudin, H.; Okarda, B.; Jelsma, I.; Pacheco, P. Certification, good agricultural practice and smallholder heterogeneity: Differentiated pathways for resolving compliance gaps in the Indonesian oil palm sector. Glob. Environ. Chang. 2019, 57, 101933. [CrossRef]

93. Hidayat, K.N.; Glasbergen, P.; Offermans, A. Sustainability Certification and Palm Oil Smallholders' Livelihood: A comparison between scheme smallholders and independent smallholders in Indonesia. Int. Food Agribus. Manag. Rev. 2015, 18, 25-48. [CrossRef]

94. Euler, M.; Schwarze, S.; Siregar, H.; Qaim, M. Oil Palm Expansion among Smallholder Farmers in Sumatra, Indonesia. J. Agric. Econ. 2016, 67, 658-676. [CrossRef]

95. IFC. Diagnostic Study on Indonesian Palm Oil Smallholders: Developing a Better Understanding of Their Performane and Potential; International Finance Corporation: Washington, DC, USA, 2013; p. 96.

96. Gillespie, P. How Does Legislation Affect Oil Palm Smallholders in the Sanggau District of Kalimantan, Indonesia? Australas. J. Nat. Resour. Law Policy 2011, 14, 1-37.

97. World Bank. Indonesia: Strategies for Sustained Development of Tree Crops. In Agriculture Operations Division; Asia Regional Office, Ed.; World Bank: Washington, DC, USA, 1989.

98. Badrun, M. Milestone of Change: Developing a Nation through Oil Palm "PIR"; Directorate General of Estate Crops: Jakarta, Indonesia, 2011; p. 229.

99. Mongabay. Indonesia Moves to End Smallholder Guarantee Meant to Empower Palm Oil Farmers. 2020. Available online: https://news.mongabay.com/2020/05/indonesia-palm-oil-plasma-plantation-farmerssmallholders/ (accessed on 30 November 2020).

100. Jelsma, I.; Slingerland, M.; Giller, K.E.; Bijman, J. Collective action in a smallholder oil palm production system in Indonesia: The key to sustainable and inclusive smallholder palm oil? J. Rural Stud. 2017, 54, 198-210. [CrossRef]

101. Daemeter. Overview of Indonesian Smallholder Farmers: A Typology of Organizational Models, Needs, and Investment Opportunities; Daemeter: Bogor, Indonesia, 2015.

102. Cramb, R.A. Palmed Off: Incentive Problems with Joint-Venture Schemes for Oil Palm Development on Customary Land. World Dev. 2013, 43, 84-99. [CrossRef]

103. Susanti, A.; Maryudi, A. Development narratives, notions of forest crisis, and boom of oil palm plantations in Indonesia. For. Policy Econ. 2016, 73, 130-139. [CrossRef]

104. Bissonnette, J.-F; De Koninck, R. The return of the plantation? Historical and contemporary trends in the relation between plantations and smallholdings in Southeast Asia. J. Peasant Stud. 2017, 44, 918-938. [CrossRef] 
105. Grass, I.; Kubitza, C.; Krishna, V.V.; Corre, M.D.; Mußhoff, O.; Pütz, P.; Drescher, J.; Rembold, K.; Ariyanti, E.S.; Barnes, A.D.; et al. Trade-offs between multifunctionality and profit in tropical smallholder landscapes. Nat. Commun. 2020, 11, 1186. [CrossRef] [PubMed]

106. Feintrenie, L.; Chong, W.; Levang, P. Why do Farmers Prefer Oil Palm? Lessons Learnt from Bungo District, Indonesia. Small-Scale For. 2010, 9, 379-396. [CrossRef]

107. Kubitza, C.; Krishna, V.V.; Alamsyah, Z.; Qaim, M. The economics behind an ecological crisis: Livelihood effects of oil palm expansion in Sumatra, Indonesia. Hum. Ecol. 2018, 46, 107-116. [CrossRef]

108. Jelsma, I.; Woittiez, L.S.; Ollivier, J.; Dharmawan, A.H. Do wealthy farmers implement better agricultural practices? An assessment of implementation of Good Agricultural Practices among different types of independent oil palm smallholders in Riau, Indonesia. Agric. Syst. 2019, 170, 63-76. [CrossRef]

109. Woittiez, L.S.; Slingerland, M.; Rafik, R.; Giller, K.E. Nutritional imbalance in smallholder oil palm plantations in Indonesia. Nutr. Cycl. Agroecosyst. 2018, 111, 73-86. [CrossRef]

110. McCarthy, J.F.; Zen, Z. Agribusiness, agrarian change, and the fate of oil palm smallholders in Jambi. In The Oil Palm Complex: Smallholders, Agribusiness and the State in Indonesia and Malaysia; Cramb, R., McCarthy, J.F., Eds.; NUS Press: Singapore, 2016; pp. 109-155. ISBN 978-981-4722-06-3.

111. Krishna, V.; Euler, M.; Siregar, H.; Qaim, M. Differential livelihood impacts of oil palm expansion in Indonesia. Agric. Econ. 2017, 48, 639-653. [CrossRef]

112. Krishna, V.V.; Kubitza, C.; Pascual, U.; Qaim, M. Land markets, Property rights, and Deforestation: Insights from Indonesia. World Dev. 2017, 99, 335-349. [CrossRef]

113. Purnomo, H.; Shantiko, B.; Sitorus, S.; Gunawan, H.; Achdiawan, R.; Kartodihardjo, H.; Dewayani, A.A. Fire economy and actor network of forest and land fires in Indonesia. For. Policy Econ. 2017, 78, 21-31. [CrossRef]

114. Zen, Z.; Barlow, C.; Gondowarsito, R.; McCarthy, J.F. Interventions to promote smallholder oil palm and socio-economic improvement in Indonesia. In The Oil Palm Complex: Smallholders, Agribusiness and the State in Indonesia and Malaysia; Cramb, R., McCarthy, J.F., Eds.; NUS Press: Singapore, 2016; pp. 78-108. ISBN 978-981-4722-06-3.

115. Aulia, A.; Sandhu, H.; Millington, A. Quantifying the Economic Value of Ecosystem Services in Oil Palm Dominated Landscapes in Riau Province in Sumatra, Indonesia. Land 2020, 9, 194. [CrossRef]

116. Ayompe, L.M.; Schaafsma, M.; Egoh, B.N. Towards sustainable palm oil production: The positive and negative impacts on ecosystem services and human wellbeing. J. Clean. Prod. 2021, 278, 123914. [CrossRef]

117. Manoli, G.; Meijide, A.; Huth, N.; Knohl, A.; Kosugi, Y.; Burlando, P.; Fatichi, S. Ecohydrological changes after tropical forest conversion to oil palm. Environ. Res. Lett. 2018, 13, 064035. [CrossRef]

118. Fitzherbert, E.B.; Struebig, M.J.; Morel, A.; Danielsen, F.; Brühl, C.A.; Donald, P.F.; Phalan, B. How will oil palm expansion affect biodiversity? Trends Ecol. Evol. 2008, 23, 538-545. [CrossRef] [PubMed]

119. Koh, L.P.; Wilcove, D.S. Is oil palm agriculture really destroying tropical biodiversity? Conserv. Lett. 2008, 1, 60-64. [CrossRef]

120. Booth, S.L. The Relationship between Carbon Emissions, Land Use Change and the Oil Palm Industry within Southeast Asia. Master's Thesis, University of San Fransisco, San Fransisco, CA, USA, 2017. Available online: https://repository.usfca.edu/capstone/562 (accessed on 30 November 2020).

121. Comte, I.; Colin, F.; Whalen, J.; Olivier, G.; Caliman, J.-P. Agricultural practices in oil palm plantations and their impact on hydrological changes, nutrient fluxes and water quality in Indonesia. A review. Adv. Agron. 2012, 116, 71-122. [CrossRef]

122. Merten, J.; Röll, A.; Guillaume, T.; Meijide, A.; Tarigan, S.; Agusta, H.; Hölscher, D. Water scarcity and oil palm expansion: Social views and environmental processes. Ecol. Soc. 2016, 21, 21. [CrossRef]

123. Obidzinski, K.; Andriani, R.; Komarudin, H.; Andrianto, A. Environmental and Social Impacts of Oil Palm Plantations and their Implications for Biofuel Production in Indonesia. Ecol. Soc. 2012, 17. [CrossRef]

124. Dislich, C.; Keyel, A.C.; Salecker, J.; Kisel, Y.; Meyer, K.M.; Auliya, M.; Wiegand, K. A review of the ecosystem functions in oil palm plantations, using forests as a reference system. Biol. Rev. Camb. Philos. Soc. 2017, 92, 1539-1569. [CrossRef]

125. Morana, L.S. Oil Palm Plantations: Threats and Opportunities for Tropical Ecosystems. Thematic Focus: Ecosystem Management and Resource Efficiency; United Nation environment Programme Global Environmental Alert Service (GEAS): Geneva, Switzerland, 2011. 
126. Safitri, L.; Sastrohartono, H.; Purboseno, S.; Kautsar, V.; Saptomo, S.; Kurniawan, A. Water Footprint and Crop Water Usage of Oil Palm (Eleasis guineensis) in Central Kalimantan: Environmental Sustainability Indicators for Different Crop Age and Soil Conditions. Water 2018, 11, 35. [CrossRef]

127. Barthel, M.; Jennings, S.; Schreiber, W.; Sheane, R.; Royston, S.; Fry, J.; McGill, J. Study on the Environmental Impact of Palm Oil Consumption and on Existing Sustainability Standards; (07.0201/2016/743217/ETU/ENV.F3); European Commission: Brussels, Belgium, 2018; Available online: https://ec.europa.eu/environment/forests/ pdf/palm_oil_study_kh0218208enn_new.pdf (accessed on 30 November 2020).

128. Azhar, B.; Lindenmayer, D.B.; Wood, J.; Fischer, J.; Manning, A.; McElhinny, C.; Zakaria, M. The conservation value of oil palm plantation estates, smallholdings and logged peat swamp forest for birds. For. Ecol. Manag. 2011, 262, 2306-2315. [CrossRef]

129. Petrenko, C.; Paltseva, J.; Searle, S. Ecological Impacts of Palm Oil Expansion in Indonesia; White Paper; International Council on Clean Transportation: Washington, DC, USA, 2016.

130. Fischer, J.; Lindenmayer, D. Landscape modification and habitat fragmentation: A synthesis. Glob. Ecol. Biogeogr. 2007, 16, 265-280. [CrossRef]

131. Gallmetzer, N.; Schulze, C.H. Impact of oil palm agriculture on understory amphibians and reptiles: A Mesoamerican perspective. Glob. Ecol. Conserv. 2015, 4, 95-109. [CrossRef]

132. Murdiyarso, D.; Van Noordwijk, M.; Wasrin, U.R.; Tomich, T.P.; Gillison, A.N. Environmental benefits and sustainable land-use options in the Jambi transect, Sumatra. J. Veg. Sci. 2002, 13, 429-438. [CrossRef]

133. Aratrakorn, S.; Thunhikorn, S. Changes in bird communities following conversion of lowland forest to oil palm and rubber plantations in Thailand. Bird Conserv. Int. 2006, 16, 71-82. [CrossRef]

134. Edwards, F.A.; Edwards, D.P.; Hamer, K.C.; Davies, R.G. Impacts of logging and conversion of rainforest to oil palm on the functional diversity of birds in Sundaland. IBIS 2013, 155, 313-326. [CrossRef]

135. Konopik, O.; Gray, C.L.; Grafe, T.U.; Steffan-Dewenter, I.; Fayle, T.M. From rainforest to oil palm plantations: Shifts in predator population and prey communities, but resistant interactions. Glob. Ecol. Conserv. 2014, 2, 385-394. [CrossRef]

136. Payán, E.; Boron, V. The Future of Wild Mammals in Oil Palm Landscapes in the Neotropics. Front. For. Glob. Chang. 2019, 2, 61. [CrossRef]

137. Danielsen, F.; Beukema, H.; Burgess, N.; Parish, F.; Brühl, C.; Donald, P.; Fitzherbert, E. Biofuel plantations on forested lands: Double jeopardy for biodiversity and climate. IOP Conf. Ser. Earth Environ. Sci. 2009, 6, 242014. [CrossRef]

138. Vijay, V.; Pimm, S.L.; Jenkins, C.N.; Smith, S.J. The Impacts of Oil Palm on Recent Deforestation and Biodiversity Loss. PLoS ONE 2016, 11, e0159668. [CrossRef]

139. Ancrenaz, M.; Oram, F.; Ambu, L.; Lackman, I.; Ahmad, E.; Elahan, H.; Meijaard, E. Of Pongo, palms and perceptions: A multidisciplinary assessment of Bornean orang-utans Pongo pygmaeus in an oil palm context. Oryx 2014, 49, 465-472. [CrossRef]

140. Baraniuk, C. Orangutans Are Hanging on in the Same Palm Oil Plantations That Displace Them, Conservationists Still Need to Work to Minimize Conflict between the Endangered Apes and Humans. Sci. Am. 2020. Available online: https://www.scientificamerican.com/article/orangutans-are-hanging-on-inthe-same-palm-oil-plantations-that-displace-them/ (accessed on 30 November 2020).

141. Jonas, H.; Abram, N.K.; Ancrenaz, M. Addressing the Impact of Large-Scale Oil Palm Plantations on Orangutan Conservation in Borneo: A Spatial, Legal and Political Economy Analysis; IIED: London, UK, 2017.

142. Nellemann, C.; Miles, L.; Kaltenborn, B.; Virtue, M.; Ahlenius, H. Last Stand of the Orang-Utan; A UNEP Rapid Response Assessment: Nairobi, Kenya, 2007.

143. Swarna Nantha, H.; Tisdell, C. The orangutan-oil palm conflict: Economic constraints and opportunities for conservation. Biodivers. Conserv. 2009, 18, 487-502. [CrossRef]

144. Suba, R.B.; van de Ploeg, J.; Zelfde, M.; Lau, Y.W.; Wissingh, T.F.; Kustiawan, W.; de Iongh, H.H. Rapid expansion of oil palm is leading to human-elephant conflicts in North Kalimantan province of Indonesia. Trop. Conserv. Sci. 2017, 10, 1940082917703508. [CrossRef]

145. Shuhada, S.N.; Salim, S.; Nobilly, F.; Lechner, A.M.; Azhar, B. Conversion of peat swamp forest to oil palm cultivation reduces the diversity and abundance of macrofungi. Glob. Ecol. Conserv. 2020, 23, e01122. [CrossRef] 
146. Paoletti, A.; Darras, K.; Jayanto, H.; Grass, I.; Kusrini, M.; Tscharntke, T. Amphibian and reptile communities of upland and riparian sites across Indonesian oil palm, rubber and forest. Glob. Ecol. Conserv. 2018, 16, e00492. [CrossRef]

147. Gillison, A.N.; Bignell, D.E.; Brewer, K.R.; Fernandes, E.C.; Jones, D.T.; Sheil, D.; May, P.H.; Watt, A.D.; Constantino, R.; Couto, E.G.; et al. Plant functional types and traits as biodiversity indicators for tropical forests: Two biogeographically separated case studies including birds, mammals and termites. Biodivers. Conserv. 2013, 22, 1909-1930. [CrossRef]

148. Unjan, R.; Nissapa, A.; Phitthayaphinant, P. An Identification of Impacts of Area Expansion Policy of Oil Palm in Southern Thailand: A Case Study in Phatthalung and Nakhon Si Thammarat Provinces. Procedia Soc. Behav. Sci. 2013, 91, 489-496. [CrossRef]

149. Anamulai, S.; Sanusi, R.; Zubaid, A.; Lechner, A.M.; Ashton-Butt, A.; Azhar, B. Land use conversion from peat swamp forest to oil palm agriculture greatly modifies microclimate and soil conditions. PeerJ 2019, 7, e7656. [CrossRef]

150. Larsen, R.K.; Jiwan, N.; Rompas, A.; Jenito, J.; Osbeck, M.; Tarigan, A. Towards 'hybrid accountability' in EU biofuels policy? Community grievances and competing water claims in the Central Kalimantan oil palm sector. Geoforum 2014, 54, 295-305. [CrossRef]

151. Córdoba, D.; Juen, L.; Selfa, T.; Peredo, A.M.; Montag, L.F.d.A.; Sombra, D.; Santos, M.P.D. Understanding local perceptions of the impacts of large-scale oil palm plantations on ecosystem services in the Brazilian Amazon. For. Policy Econ. 2019, 109, 102007. [CrossRef]

152. Tarigan, S.D. Land Cover Change and its Impact on Flooding Frequency of Batanghari Watershed, Jambi Province, Indonesia. Procedia Environ. Sci. 2016, 33, 386-392. [CrossRef]

153. Heidari, A.; Mayer, A.; Watkins, D.; Castillo, M.M. Hydrologic impacts and trade-offs associated with developing oil palm for bioenergy in Tabasco, Mexico. J. Hydrol. Reg. Stud. 2020, 31, 100722. [CrossRef]

154. Röll, A.; Niu, F.; Meijide, A.; Hardanto, A.; Hendrayanto, H.; Knohl, A.; Hölscher, D. Transpiration in an oil palm landscape: Effects of palm age. Biogeosciences 2015, 12, 5619-5633. [CrossRef]

155. Carr, M. The water relations and irrigation requirements of oil palm (Elaeis guineensis): A review. Exp. Agric. 2011, 47, 629-652. [CrossRef]

156. Chong, S.Y.; Teh, C.B.S.; Ainuddin, A.N.; Philip, E. Simple net rainfall partitioning equations for nearly closed to fully closed canopy stands. Pertanika J. Trop. Agric. Sci. 2018, 41, 81-100.

157. Farmanta, Y.; Dedi, S. Rainfall Interception by Palm Plant Canopy. 2016. Available online: http://repository. unib.ac.id/11344/1/046\%20Yong\%20F\%20\%26\%20Dedi\%20S.pdf (accessed on 30 November 2020).

158. Hardanto, A.; Röll, A.; Niu, F.; Meijide, A.; Hendrayanto; Hölscher, D. Oil Palm and Rubber Tree Water Use Patterns: Effects of Topography and Flooding. Front. Plant Sci. 2017, 8, 452. [CrossRef]

159. Bruijnzeel, L.A. Hydrological functions of tropical forests: Not seeing the soil for the trees? Agric. Ecosyst. Environ. 2004, 104, 185-228. [CrossRef]

160. Tarigan, S.; Stiegler, C.; Wiegand, K.; Knohl, A.; Murtilaksono, K. Relative contribution of evapotranspiration and soil compaction to the fluctuation of catchment discharge: Case study from a plantation landscape. Hydrol. Sci. J. 2020, 65, 1239-1248. [CrossRef]

161. Sumarga, E.; Hein, L.; Hooijer, A.; Vernimmen, R. Hydrological and economic effects of oil palm cultivation in Indonesian peatlands. Ecol. Soc. 2016, 21, 19. [CrossRef]

162. Chellaiah, D.; Yule, C.M. Effect of riparian management on stream morphometry and water quality in oil palm plantations in Borneo. Limnologica 2018, 69, 72-80. [CrossRef]

163. Juen, L.; Cunha, E.J.; Carvalho, F.G.; Ferreira, M.C.; Begot, T.O.; Andrade, A.L. Effects of oil palm plantations on the habitat structure and biota of streams in eastern Amazon. River Res. Appl. 2016, 32, 2081-2094. [CrossRef]

164. Sheaves, M.; Johnston, R.; Miller, K.; Nelson, P.N. Impact of oil palm development on the integrity of riparian vegetation of a tropical coastal landscape. Agric. Ecosyst. Environ. 2018, 262, 1-10. [CrossRef]

165. Jamaludin, N.F.; Muis, Z.A.; Hashim, H. An integrated carbon footprint accounting and sustainability index for palm oil mills. J. Clean. Prod. 2019, 225, 496-509. [CrossRef]

166. Lewis, K.; Rumpang, E.; Kho, L.K.; McCalmont, J.; Teh, Y.A.; Gallego-Sala, A.; Hill, T.C. An assessment of oil palm plantation aboveground biomass stocks on tropical peat using destructive and non-destructive methods. Sci. Rep. 2020, 10, 2230. [CrossRef] [PubMed] 
167. Khasanah, N.M.; van Noordwijk, M.; Ningsih, H. Aboveground carbon stocks in oil palm plantations and the threshold for carbon-neutral vegetation conversion on mineral soils. Cogent Environ. Sci. 2015, 1, 1119964. [CrossRef]

168. Kotowska, M.M.; Leuschner, C.; Triadiati, T.; Meriem, S.; Hertel, D. Quantifying above- and belowground biomass carbon loss with forest conversion in tropical lowlands of Sumatra (Indonesia). Glob. Chang. Biol. 2015, 21, 3620-3634. [CrossRef] [PubMed]

169. Paterson, R.R.M.; Lima, N. Climate change affecting oil palm agronomy, and oil palm cultivation increasing climate change, require amelioration. Ecol. Evol. 2018, 8, 452-461. [CrossRef]

170. Khasanah, N.M.; van Noordwijk, M.; Ningsih, H.; Rahayu, S. Carbon neutral? No change in mineral soil carbon stock under oil palm plantations derived from forest or non-forest in Indonesia. Agric. Ecosyst. Environ. 2015, 211, 195-206. [CrossRef]

171. van Noordwijk, M.; Khasanah, N.M.; Dewi, S. Can intensification reduce emission intensity of biofuel through optimized fertilizer use? Theory and the case of oil palm in Indonesia. GCB Bioenergy 2017, 9, 940-952. [CrossRef]

172. IPCC. 2013 Supplement to the 2006 IPCC guidelines for national greenhouse gas inventories: Wetlands. In Intergovernmental Panel on Climate Change (IPCC); Hiraishi, T., Krug, T., Tanabe, K., Srivastava, N., Baasansuren, J., Fukuda, M., Troxler, T.G., Eds.; IPCC: Geneva, Switzerland, 2014.

173. Khasanah, N.M.; van Noordwijk, M. Subsidence and carbon dioxide emissions in a smallholder peatland mosaic in Sumatra, Indonesia. Mitig. Adapt. Strateg. Glob. Chang. 2019, 24, 147-163. [CrossRef]

174. Rival, A.; Montet, D.; Pioch, D. Certification, labelling and traceability of palm oil: Can we build confidence from trustworthy standards? OCL 2016, 23, D609. [CrossRef]

175. Tinhout, B.; van de Hombergh, H. Setting the Biodiversity Bar for Palm Oil Certification; Assessing the Rigor of Biodiversity and Assurance Requirements of Palm Oil Standards; IUCN: Amsterdam, The Netherlands, 2019.

176. Pye, O. Commodifying sustainability: Development, nature and politics in the palm oil industry. World Dev. 2019, 121, 218-228. [CrossRef]

177. Wiggs, C.; Kuepper, B.; Piotr, M. Spot Market Purchases Allow Deforestation-Linked Palm Oil to Enter NDPE Supply Chains. Chain Reaction Research. Available online: https:/chainreactionresearch.com/report/ spot-market-purchases-allow-deforestation-linked-palm-oil-to-enter-ndpe-supply-chains/ (accessed on 30 October 2020).

178. Santika, T.; Law, E.; Wilson, K.A.; John, F.A.S.; Carlson, K.; Gibbs, H.; Morgans, C.L.; Ancrenaz, M.; Meijaard, E. Impact of Palm Oil Sustainability Certification on Village Well-Being and Poverty in Indonesia. 2020. Available online: https:/osf.io/preprints/socarxiv/5qk67/ (accessed on 30 November 2020).

179. RSPO. Impact Update 2019. In Round Table on Sustainable Palm Oil; RSPO: Kuala Lumpur, Malaysia, 2019 ; p. 52.

180. Astari, A.J.; Lovett, J.C. Does the rise of transnational governance 'hollow-out' the state? Discourse analysis of the mandatory Indonesian sustainable palm oil policy. World Dev. 2019, 117, 1-12. [CrossRef]

181. Schouten, G.; Bitzer, V. The emergence of Southern standards in agricultural value chains: A new trend in sustainability governance? Ecol. Econ. 2015, 120, 175-184. [CrossRef]

182. Higgins, V.; Richards, C. Framing sustainability: Alternative standards schemes for sustainable palm oil and South-South trade. J. Rural Stud. 2019, 65, 126-134. [CrossRef]

183. Hidayat, N.K.; Offermans, A.; Glasbergen, P. Sustainable palm oil as a public responsibility? On the governance capacity of Indonesian Standard for Sustainable Palm Oil (ISPO). Agric. Hum. Values 2018, 35, 223-242. [CrossRef]

184. Kaoem, T. A False Hope? In An Analysis of the Draft New Indonesia Sustainable Palm Oil (ISPO) Regulation; EIA: London, UK, 2020; p. 6.

185. Van Noordwijk, M.; Leimona, B.; Amaruzaman, S. Sumber Jaya from conflict to source of wealth in Indonesia: Reconciling coffee agroforestry and watershed functions. In Sustainable Development through Trees on Farms: Agroforestry in Its Fifth Decade; Van Noordwijk, M., Ed.; World Agroforestry (ICRAF): Bogor, Indonesia, 2019; pp. 177-192.

186. Erb, M.; Anggal, W. Conflict and the growth of democracy in Manggarai District. In Deepening Democracy in Indonesia.; Erb, M., Sulistiyanto, P., Eds.; Institute of Southeast Asian Studies: Singapore, 2009; pp. 283-302.

187. Setiawan, E.N.; Maryudi, A.; Purwanto, R.H.; Lele, G. Opposing interests in the legalization of non-procedural forest conversion to oil palm in Central Kalimantan, Indonesia. Land Use Policy 2016, 58, 472-481. [CrossRef] 
188. TEMPO English. Held Captive at Rokan Hulu; Tempo English: Jakarta, Indoenisa, 2016; pp. 36-37.

189. Gaveau, D.L.A.; Salim, M.A.; Hergoualc'h, K.; Locatelli, B.; Sloan, S.; Wooster, M.; Marlier, M.E.; Molidena, E.; Yaen, H.; DeFries, R.; et al. Major atmospheric emissions from peat fires in Southeast Asia during non-drought years: Evidence from the 2013 Sumatran fires. Sci. Rep. 2014, 4, 6112. [CrossRef] [PubMed]

190. Suryanata, K. Fruit trees under contract: Tenure and land use change in upland Java, Indonesia. World Dev. 1994, 22, 1567-1578. [CrossRef]

191. Robiglio, V.; Reyes, M. Restoration through formalization? Assessing the potential of Peru's Agroforestry Concessions scheme to contribute to restoration in agricultural frontiers in the Amazon region. World Dev. Perspect. 2016, 3, 42-46. [CrossRef]

192. Slingerland, M.A.; Khasanah, N.M.; van Noordwijk, M.; Susanti, A.; Meilantina, M. Improving smallholder inclusivity through integrating oil palm with crops. In Exploring Inclusive Palm Oil Production; ETFRN and Tropenbos International: Wageningen, The Netherland, 2019; pp. 147-154.

193. Khasanah, N.; Van Noordwijk, M.; Slingerland, M.; Sofiyudin, M.; Stomph, D.; Migeon, A.F.; Hairiah, K. Oil Palm Agroforestry Can Achieve Economic and Environmental Gains as Indicated by Multifunctional Land Equivalent Ratios. Front. Sustain. Food Syst. 2020, 3, 122. [CrossRef]

194. Woittiez, L.S.; van Wijk, M.T.; Slingerland, M.; van Noordwijk, M.; Giller, K.E. Yield gaps in oil palm: A quantitative review of contributing factors. Eur. J. Agron. 2017, 83, 57-77. [CrossRef]

195. Kehati. Solusi Sawitt Salam Kawasn Hutan [Oilmpalm Solutins in the Forest Zone]. SymSPOSia, Episode 10; Kehati: Jakarta, Indonesia, 2020; Available online: https://www.youtube.com/watch?v=0fsEfK5jsGU\&feature=youtu. be (accessed on 29 November 2020).

196. Nurrochmat, D.R.; Boer, R.; Ardiansyah, M.; Immanuel, G.; Purwawangsa, H. Policy forum: Reconciling palm oil targets and reduced deforestation: Landswap and agrarian reform in Indonesia. For. Policy Econ. 2020, 119, 102291. [CrossRef]

197. Iiyama, M.; Neufeldt, H.; Dobie, P.; Hagen, R.; Njenga, M.; Ndegwa, G.; Mowo, J.G.; Kisoyan, P.; Jamnadass, R. Opportunities and challenges of landscape approaches for sustainable charcoal production and use. In Climate-Smart Landscapes: Multifunctionality in Practice; World Agroforestry Centre (ICRAF): Nairobi, Kenya, 2015; pp. 195-209.

Publisher's Note: MDPI stays neutral with regard to jurisdictional claims in published maps and institutional affiliations.

(C) 2020 by the authors. Licensee MDPI, Basel, Switzerland. This article is an open access article distributed under the terms and conditions of the Creative Commons Attribution (CC BY) license (http://creativecommons.org/licenses/by/4.0/). 